\title{
Muscle stem cells in development, regeneration, and disease
}

\author{
Xiaozhong Shi ${ }^{1}$ and Daniel J. Garry ${ }^{1,2,3,4}$ \\ ${ }^{1}$ Department of Internal Medicine, University of Texas Southwestern Medical Center, Dallas, Texas 75390, USA; \\ ${ }^{2}$ Department of Molecular Biology, University of Texas Southwestern Medical Center, Dallas, Texas 75390, USA; ${ }^{3}$ Donald \\ W. Reynolds Cardiovascular Clinical Research Center at University of Texas Southwestern Medical Center, \\ Dallas, Texas 75390, USA
}

Somatic stem cell populations participate in the development and regeneration of their host tissues. Skeletal muscle is capable of complete regeneration due to stem cells that reside in skeletal muscle and nonmuscle stem cell populations. However, in severe myopathic diseases such as Duchenne Muscular Dystrophy, this regenerative capacity is exhausted. In the present review, studies will be examined that focus on the origin, gene expression, and coordinated regulation of stem cell populations to highlight the regenerative capacity of skeletal muscle and emphasize the challenges for this field. Intense interest has focused on cell-based therapies for chronic, debilitating myopathic diseases. Future studies that enhance our understanding of stem cell biology and repair mechanisms will provide a platform for therapeutic applications directed toward these chronic, life-threatening diseases.

Somatic or adult stem cell populations reside in tissues and participate in the maintenance and regeneration of their host tissues. Skeletal muscle is a dynamic tissue that is capable of responding to physiological stimuli (i.e., intense exercise training) or a severe injury by mounting a well orchestrated regenerative response that restores the cytoarchitecture within a 2-wk period (for reviews, see Hawke and Garry 2001; Cossu and Biressi 2005; Dhawan and Rando 2005; Holterman and Rudnicki 2005). The capacity for this regenerative response is primarily due to a mononuclear cell population termed satellite cells. In 1961, Alexander Mauro utilized ultrastructural techniques and identified the satellite cells as a rare cell population that is resident in adult skeletal muscle of the frog (Mauro 1961). These satellite cells were initially characterized as small, mononuclear cells that occupied a peripheral (or satellite) position in relation to the adjacent, larger multinucleated myofiber (Mauro 1961; Enesco and Puddy 1964; Moss and Leblond

[Keywords: Muscle stem cells; muscle development; muscle regeneration; myopathy; satellite cells]

${ }^{4}$ Corresponding author.

E-MAIL Daniel.garry@utsouthwestern.edu; FAX (214) 648-1450.

Article is online at http://www.genesdev.org/cgi/doi/10.1101/gad.1419406.
1971). Using these morphological techniques, the satellite cells were observed to be intercalated between the basal lamina and the plasma membrane of the adjacent myofiber (Muir et al. 1965). In response to injury or disruption of the basal lamina, the satellite cells become activated and have a remarkable proliferative capacity. Ultimately, the satellite cells either fuse to form multinucleated myotubes or re-establish a residual pool of quiescent satellite cells that have the capability of supporting additional rounds of regeneration (Moss and Leblond 1971; Schultz and Jaryszak 1985; Bischoff 1994). However, this regenerative capacity is not unlimited, as exhaustion of the satellite cell population is an important factor in the deterioration and the demise of patients that have congenital myopathies such as Duchenne Muscular Dystrophy (DMD).

In response to a severe injury or a genetic disease such as DMD, recent studies have proposed that additional stem/progenitor cell populations may be recruited and/ or have the capacity to participate in muscle regeneration and form functional myotubes (for reviews, see Hawke and Garry 2001; Cossu and Biressi 2005; Dhawan and Rando 2005; Holterman and Rudnicki 2005). The significance or the role of these stem/progenitor cells during development, disease, and regeneration is not well defined, but recent studies suggest that they not only contribute to muscle regeneration, they may also contribute to nonmuscle lineages and may serve as a vehicle for gene delivery or as a source for cell-based therapies (Hawke and Garry 2001; Cossu and Biressi 2005).

The present review will examine these issues in detail and outline the current understanding of the morphological and molecular regulation of stem cell and progenitor cell populations that participate in muscle regeneration. A discussion will focus on the genesis and molecular regulation of these stem/progenitor cells and highlight recent studies that challenge established paradigms. Importantly, this field of study remains rudimentary with regard to our understanding of the basic mechanisms that regulate the quiescence, activation, proliferation, differentiation, and self-renewal of these stem cell populations; we will highlight emerging topics of interest for this field. 


\section{Skeletal muscle development during embryogenesis}

A brief overview of muscle development during embryogenesis is warranted as studies suggest that a recapitulation of molecular networks occurs in developing and regenerating muscle. Skeletal muscle formation is derived from the paraxial mesoderm early during vertebrate embryogenesis (Buckingham et al. 2003). The paraxial mesoderm coalesces to form segmented, epithelial spheres referred to as somites that occupy paired structures on either side of the neural tube (Fig. 1A-C). The somite is further specialized to produce the dermomyotome (which is dorsal in location and generates the overlying skin and the skeletal muscle of the trunk and limbs) and the sclerotome (which is ventral in location and generates the skeleton) (Cossu et al. 1996; Miller et al. 1999; Pirskanen et al. 2000). Unlike the skeletal muscle of the torso and limbs, the genesis of head muscles is principally derived from paraxial head and prechordal mesoderm (Hauschka 1994; Christ and Ordahl 1995; Lu et al. 2002). The somites are formed in a rostral-caudal fashion, and approximately one pair of somites is formed every $2 \mathrm{~h}$ to ultimately produce a total of 60 pairs of somites in the developing mouse embryo (Figs. 1A-C, 2; Buckingham et al. 2003). Progenitors from the dermomyotome migrate in a dorsomedial fashion from the epaxial domain (which will ultimately generate the muscles of the back) or in a ventromedial fashion from the hypaxial domain (which will generate the intercostals, abdominal, and limb musculature) (Fig. 1C; Ordahl et al. 2000). These progenitors migrate beneath the dermomyotome to form the myotome and adopt a skeletal muscle fate. In response to cues from the adjacent notochord, neural tube, and lateral plate mesoderm, discrete gene expression in the progenitors results in withdrawal from the cell cycle and differentiation (Fig. 1). In addition, proliferating cells $\left(\mathrm{Pax} 3^{+} \mathrm{Pax} 7^{+}\right.$cells $)$from the central dermomyotome migrate directly to the myotome and continue to proliferate without expression of differentiation markers such as members of the MyoD family (Fig. 1C; Relaix et al. 2005). These results have challenged pre-existing notions that all myotomal cells withdraw from the cell cycle and differentiate.

Signaling factors have both permissive and repressive effects on gene expression in the epaxial and hypaxial domains of the myotome (Munsterberg and Lassar 1995; Rawls et al. 2000). For example, bone morphogenetic protein $4(\mathrm{Bmp} 4)$ is released from the adjacent neural tube and the lateral plate mesoderm and has an inhibitory effect on gene expression (i.e., Myf5 and MyoD), whereas Sonic Hedgehog and Wnts (Wnt1, Wnt3, Wnt7a, and Wnt11) are released from the adjacent notochord, neural tube, and surface ectoderm, respectively, to activate gene expression in the myotome (Fig. 1B). Collectively, these and other signaling pathways regulate a hierarchical molecular program or cascade to coordinate a balance between proliferation, specification, and differentiation of the myogenic lineage during vertebrate development.

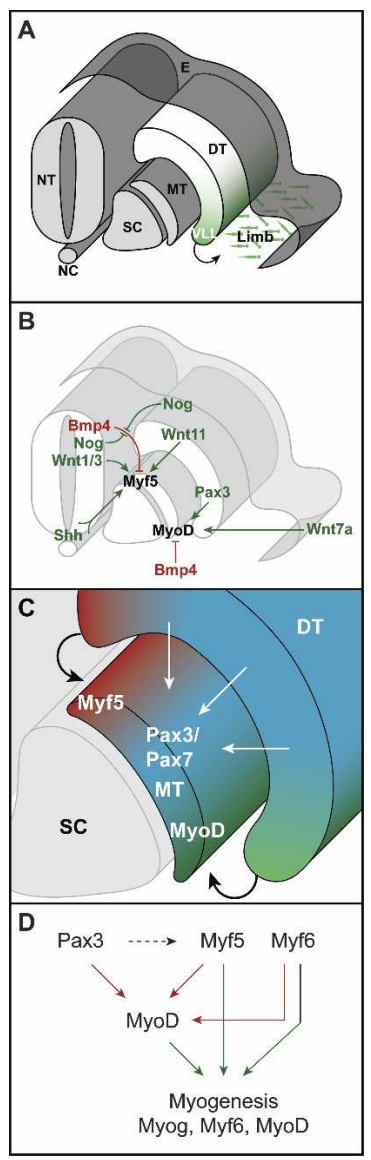

Figure 1. Developmental mechanisms direct limb myogenesis. (A) Schematic outlining the development of the somite from the paraxial mesoderm. Paired somites develop on either side of the notochord in a rostral-caudal direction. $(B)$ In response to signals or cues from adjacent lineages (i.e., notochord, neural tube, surface ectoderm), segmentation of the somite occurs into the dermomyotome, myotome, and sclerotome that are coordinated by the regulation of gene expression. Dermomyotomal cells migrate in a dorsal fashion to give rise to the epaxial myotome (the source of trunk and back muscles) and in a ventral fashion (VLL, ventrolateral lip) to give rise to the hypaxial myotome (the source of limb muscle). Progenitors delaminate and migrate from the hypaxial myotome to the developing limb. (C) The expaxial myotome (Myf5 expressing cells) and the hypaxial myotome (MyoD-expressing cells) differentiate and activate the myogenic program. In contrast, proliferating cells from the central dermomyotomal region migrate to the central region of the myotome. These cycling cells do not express members of the MyoD family, and recent studies suggest that they are the source of a majority of the satellite cells in adult skeletal muscle. $(D)$ Results of gene disruption studies support that Pax3, Myf5, and Myf6 (MRF4) are upstream regulators of MyoD during embryogenesis. (E) Surface ectoderm; (DT) dermomyotome; (MT) myotome; (SC) sclerotome; (NC) notochord; (NT) neurotube.

\section{A genetic hierarchy of gene expression governs skeletal muscle development}

The discovery of the basic helix-loop-helix (bHLH) family of transcription factors in developing skeletal muscle 


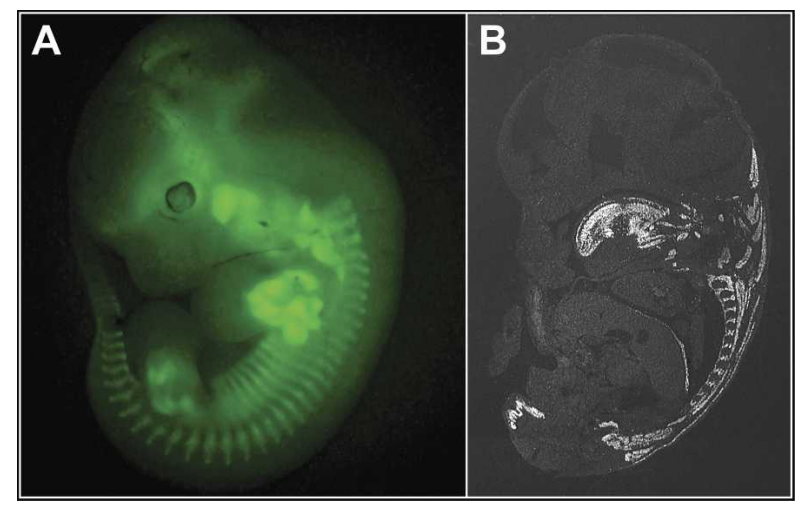

Figure 2. MyoD is expressed in somites and developing muscle during embryogenesis. (A) Whole-mount image of the MyoD promoter (containing the core enhancer and distal regulatory region)-GFP transgenic embryo at E11.5. Note expression in somites and limb muscles. (B) In situ hybridization of a parasagittal section of a E13.5 mouse embryo using a ${ }^{35}$ S-labeled MyoD riboprobe. Note expression in back, intercostal, tongue, and limb muscle groups.

including MyoD (discovered in 1987), Myf5, myogenin, and Myf6 (MRF4) provided the foundation for a regulatory molecular cascade that directs myogenesis (Davis et al. 1987; Pinney et al. 1988; Tapscott et al. 1988; Braun et al. 1989; Edmondson and Olson 1989; Rhodes and Konieczny 1989; Sassoon et al. 1989; Wright et al. 1989; Weintraub 1993). These MyoD family members are expressed in somites and established skeletal muscle during embyogenesis (Fig. 2). In a coordinated fashion, they form heterodimeric DNA-binding complexes with other bHLH transcription factors such as the E2 gene family (E47 and E12) and bind a canonical DNA sequence (CANNTG, also referred to as an E box) to regulate an array of gene expression (Weintraub et al. 1989; Lassar et al. 1991; Martin et al. 1992). Utilization of gene disruption technologies has established the essential role of the MyoD family in myogenesis (Fig. 2; Braun et al. 1992; Rudnicki et al. 1992; Hasty et al. 1993; Nabeshima et al. 1993; Patapoutian et al. 1995; Zhang et al. 1995). Previous studies suggested that only MyoD and Myf5 were important to initiate muscle identity (Rudnicki et al. 1993; Kablar et al. 2003). More recently, however, studies support the notion that MyoD, Myf5, and Myf6 are all important for the specification of the skeletal muscle lineage, as triple-mutant embryos completely lacked myoblasts and skeletal muscle fibers (Kassar-Duchossoy et al. 2004). Furthermore, analysis of single and doublemutant embryos support the premise that Myf5 and Myf6 lie upstream of MyoD in the genetic hierarchy that governs skeletal muscle development (Fig. 1D; KassarDuchossoy et al. 2004). In contrast, the fourth member of this family has a distinct role in muscle development, as the inactivation of myogenin results in perturbed muscle differentiation and neonatal lethality (Hasty et al. 1993; Nabeshima et al. 1993).

Paired-box $(\operatorname{Pax})$ transcription factors also function as key regulators of myogenesis. Pax3 exhibits broad ex- pression in the developing embryo within the hypaxial dermomyotome, the neural tube, and neural crest derivatives. Splotch mice have a mutation that disrupts the Pax3 gene, and embryos homozygous for the mutation are lethal by embryonic day 14.5 (E14.5) and have neural tube defects (exencephaly and spina bifida), neural crest cell defects, and somite defects (segmentation defects and loss of the hypaxial dermomyotome) resulting in migration failure of the muscle progenitors and an absence of limb muscles (Auerbach 1954; Franz et al. 1993; Bober et al. 1994; Goulding et al. 1994; Borycki et al. 1999). Previous studies have demonstrated that Pax3 is a transcriptional activator of the tyrosine kinase receptor Met (c-met), which functions in the delamination and migration of the muscle progenitors (Franz et al. 1993; Yang et al. 1996; Tajbakhsh et al. 1997; Dietrich et al. 1999; Brohmann et al. 2000). In support of these studies, embryos that lack Met also have an absence of limb muscles (Franz et al. 1993; Yang et al. 1996; Tajbakhsh et al. 1997; Dietrich et al. 1999; Brohmann et al. 2000). Combinatorial matings to produce embryos lacking both Pax3 and Myf5 result in an absence of body wall and limb muscle. Studies further support a regulatory network where Pax3 is genetically upstream of the Myod family members (i.e., MyoD) (Fig. 1D; Maroto et al. 1997; Tajbakhsh et al. 1997).

Recent studies reveal a partially overlapping embryonic expression pattern between the Pax3 and Pax7 (Borycki et al. 1999). Furthermore, knock-in or replacement technologies that target the Pax3 or the Pax7 locus reveal that most of the Pax 3 functions can be replaced by its paralog, Pax7, with the exception of limb muscle development (Relaix et al. 2004). Importantly, Pax7-deficient embryos have normal muscle development, suggesting that it is nonessential for embryonic muscle formation (Mansouri et al. 1996). Furthermore, gene disruption studies have identified additional regulators of myogenesis that function downstream of muscle specification, including the homeodomain transcriptional repressor Msxl and the homeodomain transcription factor Lbx1 (results in the absence of selected limb muscles) (Wang and Sassoon 1995; Bendall et al. 1999; Brohmann et al. 2000; Gross et al. 2000). Collectively, these transcriptional regulators govern the specification of the skeletal muscle lineage in the somite, the progenitor cell migration from the hypaxial domain of the dermomyotome to the limb (from the 20- to the 31-somite stage in the forelimb), the condensation of the myoblasts into premuscle masses, and the formation of primary and secondary myofibers (Hawke and Garry 2001; Cossu and Biressi 2005).

\section{Somitic origin of the satellite cell population}

The embryonic origin of muscle stem cells that reside in adult skeletal muscle has been extensively explored using a spectrum of transplantation and genetic strategies (Cossu 1997; Cossu and Mavilio 2000). Previous studies suggest that muscle stem/precursor cells including the myogenic satellite cell population originate principally 
from the somite (Fischel 1895; Le Douarin and Barq 1969; Christ et al. 1974; Armand et al. 1983; Schultz and McCormick 1994; Ordahl et al. 2000). Recent fate mapping studies support the results of early experiments and exploit the ability to manipulate the chick embryo (Gros et al. 2005; Schienda et al. 2006). In recent studies, the investigators either electroporated green fluorescent protein (GFP) into the cells of the somite, or in a separate series of experiments they grafted quail cells /which can be easily distinguished and identified in the chick muscle) within the chick somite (Gros et al. 2005; Schienda et al. 2006). Following birth, the majority (but not all) of the satellite cells were of quail origin, supporting the hypothesis that a majority of the satellite cells are derived from the central region of the dermomyotome of the somite. Alternative origins for the satellite cell population have also been proposed; these include the bone marrow or vascular components (i.e., endothelium, pericyte, mesoangioblast, etc.) (discussed below, see Fig. 3). A somitic versus a nonsomitic origin for the satellite cell population need not be mutually exclusive, as alternative sources may contribute to a greater or lesser extent in response to growth-promoting environments or in response to a severe injury or associated with disease.

\section{Myogenic stem cell identity}

Since the discovery of the satellite cell population in adult skeletal muscle, intense efforts have been directed toward the definition of molecular markers that identify this cell population. Satellite cells lack expression of the

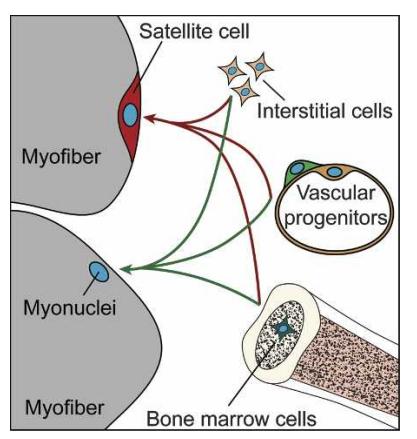

Figure 3. Somitic and nonsomitic contributions to the satellite cell pool and myofibers. Recent studies establish that the majority of the satellite cells are derived from the somite $\left(\mathrm{Pax}^{+}\right)$ $\operatorname{Pax} 7^{+}$cells located in the central region of the myotome). Other stem cell/progenitor cell populations that also contribute to the satellite cell pool and muscle regeneration include interstitial cells (muscle derived stem cells or MDSC, SP cells, $\mathrm{Cd} 45^{+} / \mathrm{Sca} 1^{+}$ cells, $\mathrm{Scal}^{+}$cells, $\mathrm{Cd} 34^{+}$cells, etc.), bone marrow cells (hematopoietic stem cells, mesenchymal stem cells, multipotent adult progenitors cells, etc.), vascular progenitors (mesoangioblasts, pericytes, endothelial progenitors), or other lineages (i.e., neural stem cells). It is unclear whether the interstitial or nonmuscle stem cell population may be a more significant source for muscle regeneration in the diseased or mypathic state (characterized by a severe, chronic injuryl. myogenic regulatory factors, including members of the Myod family (Hawke and Garry 2001). Recent studies have utilized an array of transgenic and gene disruption strategies to identify and further characterize the satellite cell population. Factors that have a restricted expression pattern and serve as markers for the satellite cells in adult skeletal muscle include cell surface receptors, adhesion proteins, growth factors, and transcription factors (Fig. 4).

\section{Receptors and adhesion proteins}

Met is a tyrosine kinase receptor for the multifunctional cytokine ligand, hepatocyte growth factor (Hgf) (Andermarcher et al. 1996). This tyrosine kinase receptor is expressed broadly during development in the myotome of the somite and neural crest derivatives and is localized to the quiescent satellite cell population in adult skeletal muscle (Andermarcher et al. 1996). Embryos lacking Met are nonviable and have an absence of limb musculature, presumably due to the failure of precursor migration from the somite (Bladt et al. 1995; Andermarcher et al. 1996; Maina et al. 1996). Expression of Met appears to uniformly label the quiescent satellite cell pool (Cornelison and Wold 1997).

M-cadherin (Cdh15) is a calcium-dependent cell adhesion molecule that is expressed in a subpopulation of the quiescent satellite cells and is up-regulated more broadly in activated satellite cells during muscle regeneration (Irintchev et al. 1994; Cornelison and Wold 1997; Beauchamp et al. 2000). Proposed functions for this integrin include the anchoring of the satellite cell to its location and/or a role in facilitating the migration of the satellite cell to areas of injury to mediate repair (Irintchev et al. 1994; Bischoff 1997; Beauchamp et al. 2000). While mice lacking m-cadherin have normal muscle development and regeneration, other cadherin proteins may substitute for the absence of m-cadherin, further suggesting the redundancy of these adhesion factors (Hollnagel et al. 2002). Other integrins and adhesion proteins that have been used as markers for satellite cells include VCAM-1 and NCAM (Covault and Sanes 1986; Jesse et al. 1998).

The sialomucin Cd34 is a cell surface glycoprotein that is expressed on endothelial cells and serves as a marker for hematopoietic stem and progenitor cells (Young et al. 1995; Cheng et al. 1996). Mice lacking Cd34 are viable, suggesting that it is nonessential for stem cell function (Krause et al. 1994). Cd34 is expressed in a subpopulation of satellite cells, but it is not restricted to this lineage in adult skeletal muscle (Beauchamp et al. 2000). Rather, expression of $\mathrm{Cd} 34$ may be associated with a specific stage or state of the satellite cell population, and therefore its use as a marker for satellite cells must be used with caution (Lee et al. 2000).

Recent studies by the Olwin laboratory /Cornelison et al. 2001) have identified the transmembrane heparin sulfate proteoglycans syndecan-3 (Sdc3) and syndecan-4 (Sdc4) as important satellite cell factors in the developing embryo and in adult muscle (Fig. 4). Using a targeted 
Figure 4. Gene expression identifies stem cell and progenitor cell populations in adult skeletal muscle. (A) Schematic outlining the role of satellite cells during muscle regeneration. In response to an injury, the quiescent satellite cell is activated by factors (including Fgfs, Hgf, activated Notch or NICD, Tnf$\alpha)$ and up-regulates MyoD expression within $2 \mathrm{~h}$ of injury. Recent studies support that satellite cells undergo self-renewal (to repopulate the residual pool) and proliferate to produce myoblasts that fuse to form newly regenerated myofibers (characterized by the central location of the nucleus). (B) Schematic outlining the gene expression of the myogenic stem cell pool (MSC or satellite cells), myogenic progenitor cells (MPC or those characterized by expression of MyoD, Myf5, or Myf6), myoblasts (characterized by myogenin or desmin expression), and the multinucleated myotube. Additional studies will be necessary to dissect the gene expression and establish the hierarchy of the heterogeneous satellite (MSC) pool. MPC and myoblasts may be equivalent to the transit amplifying cells described in skin and gut. (Sdc3/4) Syndecan 3 and 4; (Cdh15) m-cadherin; (Myog) myogenin; (Des) desmin; (Met) c-met.

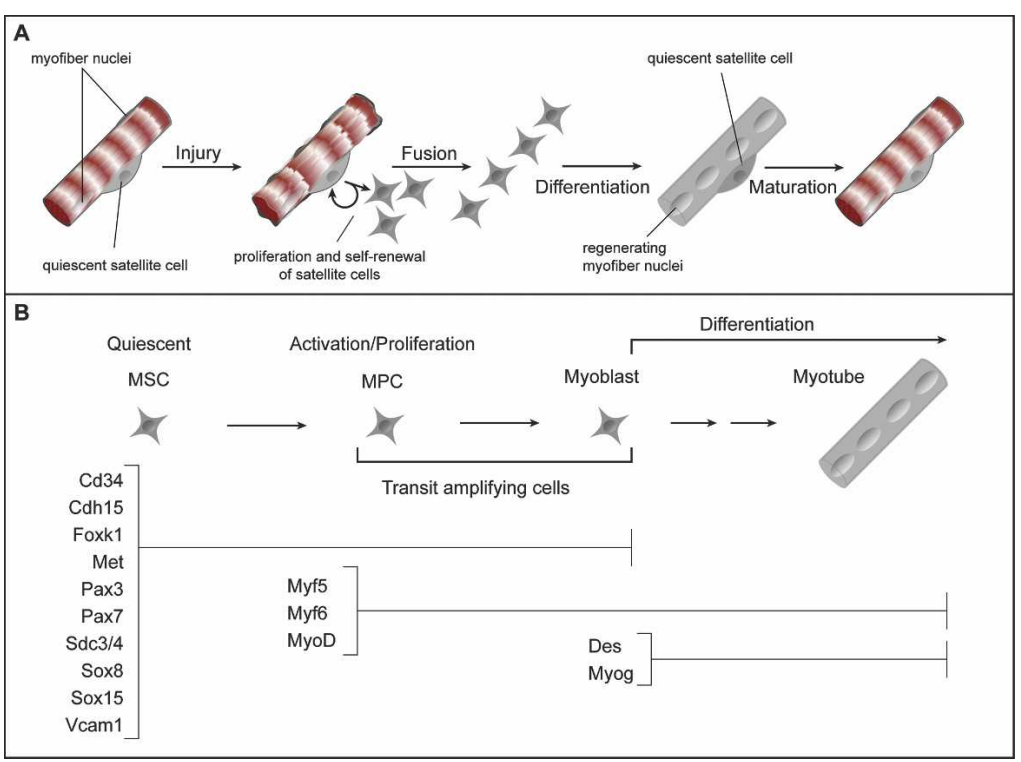

gene disruption strategy, distinct satellite cell defects were associated with the loss of either syndecan protein (Cornelison et al. 2004). Syndecan-3-null mice were shown to exhibit impaired locomotion, hyperplasia of satellite cells and myocytes, extensive fatty infiltrates, and fibrosis of the skeletal muscle. Aspects of this phenotype are further observed in other dystrophic muscle models (Bell and Conen 1968). In contrast, the syndecan4-null satellite cells have impaired activation, proliferation, and differentiation of the mutant satellite cells resulting in a perturbed regenerative response to injury (Cornelison et al. 2004). Future studies will be needed to explore the role of each of these syndecans in satellite cell signal transduction in response to stimuli associated with growth, aging, and injury.

\section{Nuclear factors}

Transcription factors govern molecular cascades that ultimately regulate the fate of cell populations. Foxk1 is a member of the forkhead/winged helix transcription factor family and is expressed in the quiescent and proliferating satellite cell population during the latter stages of embryogeneis, postnatal, and adult skeletal muscle (Fig. 4; Garry et al. 1997, 2000). Members of the forkhead/winged helix transcription factor family regulate cell fate, patterning, and cell cycle kinetics of stem cell and progenitor cell populations. Using an array of biochemical techniques, we have demonstrated that Foxk1 is an upstream regulator of the cyclin-dependent kinase inhibitor $p 21^{C I P}$ in the satellite cell population (Garry et al. 2000; Hawke et al. 2003). Mice lacking Foxk1 are growth retarded and have a severe impairment in skeletal muscle regeneration. The impairment of skeletal muscle regeneration is due to decreased numbers of satellite cells and impaired cell cycle kinetics (Hawke et al. 2003).
Recent studies suggest that Sox transcription factors are upstream regulators of Foxk1. Sox transcription factors are found in all metazoan species and play key roles in embryonic development. Sox factors contain a DNAbinding domain (i.e., HMG domain) that doubles as both the DNA-binding moiety and the major interface for protein-protein interaction (Wilson and Koopman 2002). Therefore, specificity of the Sox factor is, in part, dependent on the factors that partner with Sox proteins either to activate or repress transcription from target promoters (Beranger et al. 2000; Wilson and Koopman 2002; Schmidt et al. 2003). Sox8 and Sox 15 are expressed in the satellite cell population in adult skeletal muscle (Fig. 4; Schmidt et al. 2003; Lee et al. 2004). Biochemical and overexpression studies suggest that these Sox factors inhibit myogenesis through the transcriptional repression of MyoD family members (Schmidt et al. 2003). Moreover, mice lacking Sox15 are viable but appear to have impaired skeletal muscle regeneration (Lee et al. 2004). Utilizing a yeast two-hybrid assay, recent studies report that Sox factors may interact with Paired-box transcription factors to coregulate gene expression (Wilson and Koopman 2002).

Elegant studies undertaken by the Buckingham laboratory have targeted the Pax3 locus using the GFP reporter (Relaix et al. 2005). Analysis of this reporter model revealed that Pax 3 and its paralog, Pax7, are coexpressed in a majority $(\sim 87 \%)$ of the myotomal cells of the somite during embryogenesis (Relaix et al. 2005). Moreover, a majority of these $\mathrm{Pax} 3^{+} \mathrm{Pax} 7^{+}$myotomal cells were proliferating cells that sharply contrasted with the decreased proliferative index of the myotomal cells that expressed MyoD or Myf5. During the latter stages of development, these $\mathrm{Pax} 3^{+} \mathrm{Pax} 7^{+}$cells lacked MyoD expression and served as progenitors that subsequently formed skeletal muscle (Relaix et al. 2005). Furthermore, these Pax3-GFP cells assumed a satellite cell position (i.e., be- 
neath the basal lamina) (Fig. 5) in the E18.5 embryo and in adult skeletal muscle, further emphasizing an essential role for Pax transcription factors for the specification of a myogenic fate (Montarras et al. 2005). Pax7 mutant mice have normal muscle development, and while satellite cells are present initially, they are not maintained during the postnatal period, suggesting a role for Pax7 in the maintenance (or as an antiapoptotic factor) of the satellite cell (Mansouri et al. 1996; Seale et al. 2000; Oustanina et al. 2004; Relaix et al. 2006). Additional studies verify that the Pax7 mutant mouse has a severe impairment in muscle regeneration (Kuang et al. 2006; Relaix et al. 2006).

\section{The satellite cell niche and the influence of permissive and repressive factors}

Satellite cells are abundant during the neonatal period, as estimates suggest that upward of $30 \%$ of nuclei in the neonatal hindlimb skeletal muscle are sublaminar satellite cells (Snow 1977; Bischoff 1994). Following the growth period where satellite cells fuse to myofibers, this cell population is reduced to $2 \%-5 \%$ of the hindlimb nuclei in adult skeletal muscle (the number of satellite cells is dependent on species, age, and muscle fiber type) (Fig. 5; Snow 1977; Allam 1981; Campion et al. 1981; Hawke and Garry 2001). Future initiatives for this field will evaluate the relationship between neonatal versus adult satellite cells (i.e., the definition of the molecular regulation of the respective cell populations), the heterogeneity of the satellite cell pool in adult skeletal muscle (i.e., the definition of a hierarchy of satellite cells), and the relationship of satellite cells resident in oxidative slow-twitch muscle groups (i.e., soleus muscle) compared with those cells resident in the fast-twitch glycolytic muscles (i.e., extensor digitorum longus muscle).

The myogenic satellite cell has an anatomically defined specialized niche (Fig. 5) that ultimately governs the state of this cell population (i.e., quiescence, activation, proliferation, etc.) (Fig. 6). The adjacent differentiated myofiber, innervating motor neurons, infiltrating inflammatory cells, and the vascularization collectively

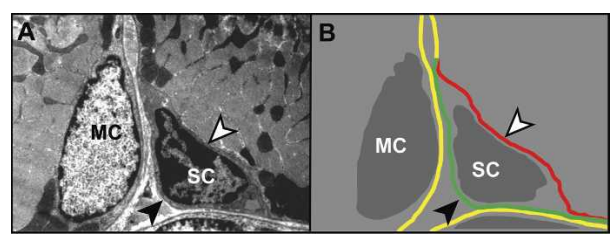

Figure 5. The satellite cells have a specialized niche in adult skeletal muscle. (A) Electron micrograph of adult skeletal muscle demonstrating the myocyte nucleus (MC) and the satellite cell nucleus (SC). Note that the satellite cell is characterized by its size (i.e., small), high nuclear to cytoplasm ratio, relative absence of cytoplasmic organelles, and increased nuclear heterochromatin representing a quiescent state of the cell. (B) Schematic of $A$ emphasizing that the satellite cell lies between the basal lamina (black arrowhead or green line) and the sarcolemma (white arrowhead or red line).

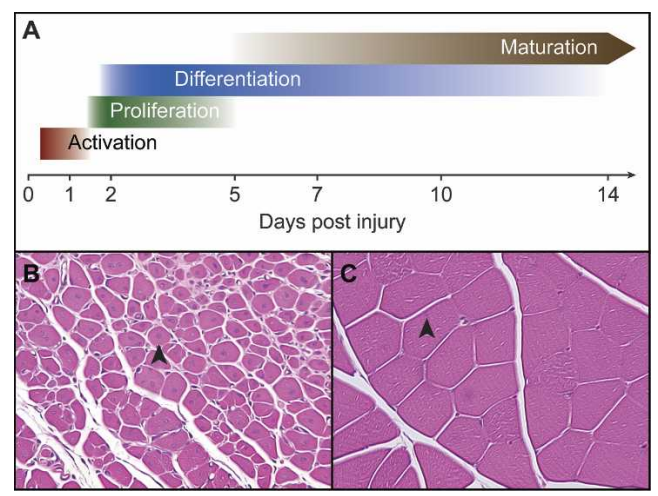

Figure 6. Muscle repair is characterized by discrete stages of regeneration. (A) Schematic outlining the stages of regeneration including the activation of satellite cells (within $2 \mathrm{~h}$ of injury), satellite cell proliferative (or transit amplifying cell) stage (cellular proliferation peaks at days 2-3 following injury), differentiation (characterized by the formation of centronucleated myofibers), and maturation. (B) Following an intramuscular injection of cardiotoxin (a myonecrotic agent), $\sim 70 \%-90 \%$ of the muscle is destroyed. Regeneration by stem/progenitor cells results in the formation of small, centronucleated (slightly basophilic) myofibers between 5 and 7 d post-injury (arrowhead marks the centronucleus of the newly regenerated myofiber). (C) Hematoxylin and eosin-stained transverse section of postinjured skeletal muscle reveals restoration of the cellular architecture within $\sim 2$ wk of injury. The nucleus occupies a peripheral position in fully mature myofibers.

establish the niche in which the satellite cell resides (Schmalbruch and Hellhammer 1977; Gibson and Schultz 1982; Wokke et al. 1989; Brown and Stickland 1993). The release of cytokines, neurotrophic factors, growth factors, or oxygen tension /which mediates the hypoxia-inducible gene program such as $\operatorname{Hif} 1 \alpha, \operatorname{Hif} 2 \alpha$, NO, Vegf, etc.) collectively orchestrates and modulates the status of the satellite cell pool. For example, recent studies have established that a hypoxic microenvironment maintains an undifferentiated state of selected cell populations. In a series of experiments, the induction of Hif $1 \alpha$ was shown to activate Notch downstream genes to maintain the stem/progenitor cell state /Gustafsson et al. 2005).

Skeletal muscle is a source for insulin-like growth factors (Igf1 and Igf2) that function as hormones and as paracrine factors (Allen and Boxhorn 1989; LeRoith et al. 1992). A detailed analysis has been undertaken for the functional roles for Igf1 in skeletal muscle, which are multiple and complex. This complexity is attributable to the four isoforms for Igf1 that originate through genetic and protein processing. The use of mouse genetics has established roles for Igf 1 in the modulation of inflammation and decreased scar formation mediated in part by the down-regulation of Tgfb during muscle regeneration (Barton et al. 2002; Shavlakadze et al. 2004). Transgenic overexpression of Igf1 in skeletal muscle restores the regenerative capacity of aging skeletal muscle through the promotion of satellite cell activation, satellite cell proliferation, and the recruitment of nonmuscle stem cells 
from the bone marrow (Barton-Davis et al. 1998; Musaro et al. 2001, 2004). These functional roles for Igf1 are mediated by a number of signaling pathways in skeletal muscle including the calcineurin/NFAT pathway to mediate hypertrophy, PI3K/Akt/mTOR to increase protein synthesis and promote cell survival, and mitogen-acitvated protein kinase kinase (MAPKK) pathway to promote satellite cell activation and proliferation (Mourkioti and Rosenthal 2005; Song et al. 2005). Further studies will be necessary to further explore the role of Igfl isoforms on the regulation of stem cell activity and examine clinical applications for the use of recombinant human Igf1 for the treatment of myopathies (Mourkioti and Rosenthal 2005).

The Tgfb superfamily stimulates and represses stem cell activity and regeneration. Myostatin (Gdf8) is a member of the Tgfb family that is expressed in skeletal muscle satellite cells and myoblasts (McCroskery et al. 2003). Bovine (Belgian Blue and Piedmontese) and genetic murine models that lack myostatin have extensive muscle hypertrophy referred to as a double-muscling phenotype (Kambadur et al. 1997; McPherron et al. 1997). Using isolated fiber preparations and satellite cell/ myoblast cultures, data suggest that myostatin may function to maintain satellite cell quiescence and repress self-renewal in part through the induction of $\mathrm{p} 21^{\mathrm{CIP}}$ (Cdkn1a) (McCroskery et al. 2003). Recent studies further suggest that the modulation of growth-inhibitory factors such as myostatin in myopathic models results in increased muscle regeneration (McCroskery et al. 2005). These preclinical studies have led to the use of small molecule inhibitors of myostatin in clinical trials.

Hgf or Scatter factor (SF) is a $90-\mathrm{kDa}$ protein that is tethered to the extracellular matrix in skeletal muscle and is released in response to mechanical stretch or injury by a nitric oxide (NO)-dependent mechanism (Michalopoulos and Zarnegav 1992; Miller et al. 2000; Sheehan et al. 2000; Anderson and Pilipowicz 2002; Tatsumi et al. 2002; Tatsumi and Allen 2004). The activated Hgf is a ligand for the c-met receptor and is a potent activator of the satellite cell population promoting cell cycle reentry (from the G0 quiescent state to G1) by transducing the p38 MAPK and PI3K signaling pathways /Cornelison and Wold 1997; Tatsumi et al. 1998; Weston et al. 2003; Jones et al. 2005; Lluís et al. 2006; Wozniak et al. 2005). Unresolved issues include the definition of the mechanism of NO-mediated release of Hgf as well as the role of $\mathrm{NO}$ and Hgf on non-satellite cell progenitors that participate in muscle regeneration.

Fibroblast growth factors have multiple isoforms and are released from damaged myofibers to further promote the proliferation of activated satellite cells (Clegg et al. 1987; Clarke et al. 1993; Johnson and Allen 1995; Cornelison et al. 2001, 2004; Yablonka-Reuveni and Anderson 2006). Transduction of the FGF signal is mediated through one of four transmembrane tyrosine kinase receptors (Fgfr1-Fgfr4) that are expressed on the satellite cell membrane and requires heparin sulfate to mediate the intracellular signal (Rapraeger et al. 1991; Cornelison et al. 2001). Previous studies have established that the role of Fgfs on satellite cell proliferation is mediated via the Raf/ERK signaling pathway (Jones et al. 2001). Furthermore, studies have explored the modulatory effects of Fgfs (including Fgf6) on myogenic differentiation (Seed and Hauschka 1988; Rando and Blau 1994; Sheehan and Allen 1999; Cornelison et al. 2001; Armand et al. 2003). Fgf6 is relatively restricted to the myogenic lineage and is induced in response to injury (Goetsch et al. 2003). Independent efforts to genetically ablate Fgf6 have resulted in a variable phenotype with one group reporting a normal phenotype and another group reporting a severe regenerative defect in the absence of Fgf6 (Floss et al. 1997; Fiore et al. 2000). These differential phenotypic results remain unresolved but may be due to strain differences and the presence of modifier genes. Additional studies will be necessary to explore the collective interaction of Fgfs and other growth factors in the regulation of the satellite cell fate in response to injury and regeneration. These additional factors include, but are not limited to, Pdgf, Egf, Lif, Tnf- $\alpha$, Tgfb, NO, Il4, etc. (Nathan 1987; Austin and Burgess 1991; Kurek et al. 1997; Anderson 2000; Horsley et al. 2003; Li 2003).

\section{Self-renewal of myogenic stem cell populations}

Skeletal muscle has the capacity for complete regeneration and restoration of the cellular architecture in response to repeated injuries. This ability to withstand multiple injuries implies that the satellite cell pool is replenished during the regenerative process (Fig. 5A; Moss and Leblond 1971; Schultz and Jaryszak 1985; Schultz 1996). Previous pulse-chase experiments (using tritiated thymidine or BrdU to label cells in S phase of the cell cycle as a measure of cellular proliferation) have suggested that the satellite cell pool was heterogenous and promoted the notion that a pool of satellite cells maintained a residual pool consistent with a self-renewal mechanism (Moss and Leblond 1971; Schultz 1996). These studies further supported the presence of a cycling pool of satellite cells that may be similar to the transit amplifying cell (TAC) population described in other lineages (i.e., skin and gut) (Blanpain et al. 2004; Tajbakhsh 2005). More recent studies using cultured myofibers demonstrate that activated satellite cells principally differentiate and express MyoD family members (Fig. 5B). In contrast, activated satellite cells may exit the cell cycle, re-establish a quiescent state, and be stimulated to re-enter the cell cycle, suggesting that satellite cells are capable of self-renewal or replenishment of a residual pool of cells (Halevy et al. 2004; Olguin and Olwin 2004; Zammit et al. 2004). Direct evidence for a self-renewal mechanism for the satellite cell pool was established following the transplantation of genetically labeled myofibers (genetically labeled with the LacZ reporter) into the hindlimb musculature of the irradiated mdx myopathic mouse model. In this study, radiation ablation of the dystrophic muscle inactivated the endogenous muscle stem cells. Collins et al. (2005) observed that the transplantation of one myofiber containing as few as seven satellite cells gave rise to $>100$ new myofi- 
bers containing $>25,000$ differentiated donor myonuclei. Importantly, these transplanted satellite cells gave rise to anatomically distinct satellite cells that participated in the repopulation of myofibers following a newly induced injury with a myotoxin (Collins et al. 2005). The mechanism that directs the self-renewal mechanism remains to be determined, but studies suggest that the transcription factor, Pax7, or the Notch/Numb signaling pathway may participate in these cell fate decisions (Conboy and Rando 2002; Halevy et al. 2004; Olguin and Olwin 2004). Further studies will unravel the mechanisms that direct the self-renewal process, define the proliferative capacity of the satellite cell population in vivo, and define a hierarchical satellite cell cascade. It is likely that a stem cell/progenitor cell hierarchy comparable to the hematopoietic system exists for the satellite cell pool (i.e., stem cells vs. transit amplifying progenitors vs. progenitors) (Weissman 2000). The definition of this satellite cell hierarchy will serve as a platform for cell-based therapies.

\section{Repositories of stem cell and progenitor cell populations for repair of skeletal muscle}

While studies have clearly established the myogenic potential of satellite cells, other cell populations have been shown to participate in limited muscle regeneration. These stem cell populations either reside in skeletal muscle or may be recruited from nonmuscle pools in response to signals or cues associated with injury and regeneration (Fig. 3). Selected cell populations will be highlighted as cellular sources for muscle regeneration.

Previous studies have established that Cd45, a hematopoietic-restricted marker, identifies a cell population that has a myogenic capacity following induction by the Wnt signaling pathway (Polesskaya et al. 2003). Moreover, these $\mathrm{Cd} 45^{+}: \mathrm{Sca}^{+}$(Ly6a) cells lack a myogenic potential when isolated from unperturbed skeletal muscle but acquire a myogenic potential when isolated from injured muscle (Polesskaya et al. 2003). Using genetic mouse models, studies demonstrated that the $\mathrm{Cd} 45^{+}: \mathrm{Sca}^{+}$cells, in adult skeletal muscle, require Pax 7 for myogenesis during regeneration (Seale et al. 2004).

The bone marrow is a further source of stem cell populations that has myogenic potential. Using genetically labeled mouse models, marrow-derived cells have been shown to be recruited to injured muscle and to generate fully differentiated myofibers (Ferrari et al. 1998). Bone marrow-derived multipotent adult progenitors $\left(\mathrm{Cd}_{1}{ }^{+} /\right.$ $\left.\mathrm{Sca}^{-} / \mathrm{Flk} 1^{-} / \mathrm{Cd} 45^{-} / \mathrm{Cd} 31^{-}\right)$are capable of forming differentiated myotubes in vitro and in vivo following the delivery into murine muscle (Jiang et al. 2002; Muguruma et al. 2003; Reyes et al. 2005). Studies undertaken in the Blau laboratory (LaBarge and Blau 2002; Corbel et al. 2003) have demonstrated that GFP-labeled bone marrowderived cells become satellite cells that are capable of myogenesis and the formation of labeled myofibers. Further support of these results was undertaken using parabiotic joined mice. The parabiotic mouse model joins two genetically distinct mice that develop a common vascular system, and these studies demonstrated that bone marrow-derived cells formed skeletal myofibers in injured and physiologically stressed muscle in the absence of other injuries (i.e., irradiation damage) (Sherwood et al. 2004; Palermo et al. 2005).

Side population (SP) cells constitute a stem cell/progenitor cell population that resides in adult tissues including bone marrow and skeletal muscle (Goodell et al. 1996, 1997; Meeson et al. 2004). Using a DNA-binding dye (Hoechst33342) and dual-wavelength flow cytometry, SP cells are identified based on their ability to efflux the Hoechst33342 dye (Goodell et al. 1996, 1997; Montanaro et al. 2004). The ability to efflux this DNA-binding dye is due to the multidrug resistance protein, Abcg2 (Zhou et al. 2001; Martin et al. 2004). Previous studies have established that SP cells are capable of myogenesis in vitro and in vivo (Gussoni et al. 1999; Asakura et al. 2002; Bachrach et al. 2004; Meeson et al. 2004). SP cells increase in number following muscle injury, have a distinct molecular signature, and participate in muscle regeneration (Meeson et al. 2004). Muscle SP cells are characterized as Sca $1^{\text {high }}$ and $\mathrm{Cd} 45^{\text {low }}(>80 \%$ of the SP cells express Sca1 and $\sim 10 \%-15 \%$ of the SP cells express Cd45) (Gussoni et al. 1999; Meeson et al. 2004). SP cells in skeletal muscle have been shown to be decreased in number (Meeson et al. 2004) or have normal numbers (Seale et al. 2000) in genetic null mouse models. Recent studies undertaken by the Kunkel laboratory (Schienda et al. 2006) utilizing different types of labeling techniques in chick and mouse reveal that at least a subpopulation of skeletal muscle SP cells is derived from Pax3 ${ }^{+}$ hypaxial somitic cells. Future studies will further explore the developmental origin of all muscle SP cells and the relationship of the SP cells to vascular progenitors and satellite cell populations.

Vascular constituents have been shown to have a myogenic potential (Fig. 3). Cossu's laboratory (De Angelis et al. 1999; Minasi et al. 2002; Sampaolesi et al. 2003) has demonstrated that vessel-associated progenitors (mesoangioblasts) isolated from the dorsal aorta have myogenic potential and are capable of participating in muscle regeneration. In support of these results, fate-mapping studies revealed that descendants of Flk1 (Kdr)-expressing cells contributed to the skeletal muscle lineage generating labeled myofibers (Motoike et al. 2003). Flk1 is the receptor for vascular endothelial growth factor and is expressed in the earliest progenitors of the endothelial and hematopoietic lineages (Motoike et al. 2003). Other vascular components such as endothelial progenitors and pericytes have also been proposed as having myogenic potential (Tavian et al. 2005).

Additional stem cell populations that have been isolated from adult skeletal muscle include muscle-derived stem cells (MDSC that are $\left.\mathrm{Cd} 34^{+} / \mathrm{Sca}^{+}\right), \mathrm{Sca}^{+}$cells, $\mathrm{Cd} 34^{+}$cells, and neural stem cells (neurospheres), which all have myogenic potential (Galli et al. 2000; Lee et al. 2000; Tamaki et al. 2002, 2005; Deasy et al. 2005; Mitchell et al. 2005). These studies emphasize the capacity of stem cell/progenitor cell populations to undergo the self-renewal, increased proliferation (up to 300 dou- 
blings), and reprogramming associated with culture conditions (Galli et al. 2000; Lee et al. 2000; Tamaki et al. 2002, 2005; Deasy et al. 2005; Mitchell et al. 2005). Additional studies will be necessary to define the hierarchy of these stem cell/progenitor cell populations, their relationship to satellite cells, and their capacity to participate in the growth, maintenance, and regeneration of skeletal muscle in response to injury and disease.

\section{Plasticity and potential of stem cells and progenitor cells in adult skeletal muscle}

Multipotentiation or plasticity is a characteristic of stem cell and progenitor cell populations. Recent studies have clearly demonstrated that satellite cells and other progenitor cell populations that are resident in adult skeletal muscle are capable of generating other mesodermal derivatives (Hu et al. 1995; Jackson et al. 1999; Asakura et al. 2001; Holst et al. 2003). These studies demonstrate that myogenic stem/progenitors are capable of generating nonmuscle lineages including blood derivatives, vascular components, osteoblasts, and adipocytes in response to specific signals (Jackson et al. 1999). For example, satellite cells that are cultured in the presence of bone morphogenic proteins (i.e., Bmp2) promote the osteogenic molecular program with an induction of the master transcriptional regulators Runx2 and Osterix (Fux et al. 2004). Similarly, intense interest has recently focused on the transdifferentiation of muscle progenitors to the adipogenic lineage. This interest is fueled by the observation that myopathic skeletal muscle is characterized by the replacement of myofibers by adipose tissue. Induction of the master regulators peroxisome proliferating activating receptor- $\gamma(\operatorname{PPAR} \gamma)$ and CCAATenhancer binding protein- $\alpha$ (Cebpa) in satellite cells results in the transdifferentiation to the adipogenic lineage. While the regulatory cascade for adipogenesis in myogenic progenitors is incompletely defined, signaling pathways, such as the Wnt/ $\beta$-catenin, the Rho GTPase, and IL-15 pathways, have been implicated in this process (Ross et al. 2000; Taylor-Jones et al. 2002; Sordella et al. 2003; Akimoto et al. 2005; Quinn et al. 2005; Vertino et al. 2005). In addition to the mesodermal derivatives, myogenic stem/progenitor cell populations may have a broader potential and may generate lineages from other germ layers such as the neuronal lineage (Tamaki et al. 2005). An alternate but not mutually exclusive possibility is that satellite cells can be directed toward a mesenchymal alternative differentiation (MAD) program prior to the generation of nonmuscle lineages (Shefer et al. 2004). Future studies will be necessary to fully decipher the capacity of the myogenic progenitors in vivo to generate other lineages within the regenerating skeletal muscle (i.e., vasculature, peripheral nerve, etc.) and other lineages (i.e., myocardial, neuronal, etc.). These studies will enhance our understanding of regeneration and may serve as a platform for progenitor cell-based therapies for non-skeletal muscle diseases (i.e., cardiomyopathies).

\section{Regenerative mechanisms}

Skeletal muscle is a highly regenerative tissue that is second only to bone marrow with regards to its regenerative capacity. Numerous injury models have been proposed to examine skeletal muscle regenerative mechanisms, including crush, freeze, and chemical injuries. Perhaps the most reproducible injury utilizes chemical agents including cardiotoxin, notexin, or barium chloride (d'Albis et al. 1988; Garry et al. 1997; Cornelison et al. 2004). In response to a chemical-induced injury, a well orchestrated cellular and molecular response is observed (Fig. 6). Immediately following injury, myofibers hyalinize, vacuolate, and lyse (Goetsch et al. 2003). Morphological analysis reveals interstitial edema with neutrophils that release trophic factors to activate the satellite cells within $2 \mathrm{~h}$ of injury (Fig. 6). A marked inflammatory response is characterized by the presence of lymphocytes and macrophages that begin to phagocytose necrotic myofibers (Goetsch et al. 2003). Following activation of the satellite cell population, they re-enter the cell cycle and demonstrate a significant proliferative capacity between 2 and $3 \mathrm{~d}$ following injury. This proliferative period is followed by a differentiation phase where myoblasts withdraw from the cell cycle and form small basophilic centronucleated myotubes (the hallmark of skeletal muscle regeneration) (Fig. 6; Goetsch et al. 2003). Fusion of myoblasts and further growth of the newly regenerated centronucleated myofibers ultimately results in restoration of the cellular architecture within an 2 -wk period (Goetsch et al. 2003).

Similarly, the molecular signature of regenerating muscle is coordinated and complex. Using transcriptome analyses, numerous studies have characterized the molecular profile of gene expression that governs discrete stages of stem cell and progenitor cell populations during muscle regeneration. Hoffman's laboratory (Zhao and Hoffman 2004) undertook an extensive transcriptome analysis as they interrogated 27 regenerative time periods following cardiotoxin-induced muscle injury. In addition, studies using microarray analysis have focused on cell cycle kinetics, the extracellular matrix, or mouse models that have ongoing degeneration-regeneration cycles (Tseng et al. 2002; Goetsch et al. 2003; Porter et al. 2003; Yan et al. 2003; Turk et al. 2005). Collectively, these and other studies demonstrate the induction of MyoD and Myf6 within 2-6 h of injury, corresponding to their role in activation of the satellite cell population (Grounds et al. 1992; Megeney et al. 1996; Nicolas et al. 1996; Garry et al. 2000). Myf5 is delayed in expression, peaks within $5 \mathrm{~d}$ of injury, and has a similar expression pattern to myogenin. The Notch/Numb, Fgf, and Neuregulin pathways were dynamically regulated in addition to the extracellular matrix factors tenascin C, thymosin B4, and MMPs, which have multiple roles including the modulation of cellular migration of the satellite cell pool (Goetsch et al. 2003; Turk et al. 2005). Transcriptional regulators including Paired-box factors (Pax3 and Pax7), Forkhead, and Sox family members are up-regulated during the repair and regenerative period /Goetsch et al. 
2003; Turk et al. 2005). This strategy has provided a global analysis of the molecular regulation of stage-specific gene expression during the degeneration-regeneration period and has provided a foundation to further define regulatory cascades that govern the regenerative process.

\section{Muscle diseases and aging}

Congenital and acquired myopathies are common and deadly. The most common lethal myopathic disease is $\mathrm{DMD}$, which is an $\mathrm{X}$-linked recessive disease that afflicts 1:3500 males. In 1986, the Kunkel laboratory identified dystrophin as the disease-causing gene (Hoffman et al. 1987). Dystrophin is $2.4 \mathrm{Mb}$ in size and is the largest known mammalian gene (Hoffman et al. 1987). DMDafflicted patients are diagnosed early in childhood. This progressive muscle-wasting disease affects striated muscle including limb muscles, diaphragm, and heart (Watkins and Cullen 1988). The final stages of disease are characterized by cardiorespiratory failure, and death usually occurs in the teenage years or early 20s. The most common mouse model for DMD is the dystrophin mutant $m d x$ mouse model that was described in 1984 (Bulfield et al. 1984). The phenotypic changes in the $m d x$ mouse model are less pronounced compared with the DMD patients, but the mutant mouse has ongoing cycles of degeneration and regeneration of skeletal muscle (peaking at 3-10 wk of age) and an increase in fat and fibrosis of the skeletal muscle (Bell and Conen 1968; DiMario et al. 1991; Matsuda et al. 1995; Straub et al. 1997; Briguet et al. 2004). The $m d x$ mice also have spinal abnormalities (i.e., kyphosis) and a dilated cardiomyopathy (Briguet et al. 2004; Laws and Hoey 2004; Quinlan et al. 2004). A genetic mouse model that may have a more severe myopathy and limited survival is the utrophindystrophin double-mutant mice (Deconinck et al. 1997). Studies suggest that the double-mutant mice may more accurately represent the pathobiology observed in the DMD patient (Deconinck et al. 1997).

Recent studies have established an important role for Lamin A/C and emerin in satellite cell differentiation (Bakay et al. 2006; Frock et al. 2006; Melcon et al. 2006). Mutations within Lamin A are associated with EmeryDreifuss and Limb-Girdle muscular dystrophy patients. Mice lacking lamin A/C have impaired myogenic differentiation as a result of perturbed pathways or networks regulated by the retinoblastoma and MyoD genes (Bakay et al. 2006; Frock et al. 2006; Melcon et al. 2006). These studies underscore the role of Lamin $\mathrm{A} / \mathrm{C}$ and emerin for the coordinated regulation of cell cycle kinetics and terminal differentiation.

Utilizing a gene disruption strategy, additional genetic mouse models have been generated that have myopathic or regenerative defects including dystrophin-glycoprotein complex (DGC) mutant mice (i.e., sarcoglycan mutants), sarcomeric mutant mice (i.e., desmin-null mice), Pax7-null mice, Foxk1-null mice, and syndecan-4-null mice (Garry et al. 2000; Seale et al. 2000; Allikian et al. 2004; Cornelison et al. 2004; McNally and MacLeod 2005; Barresi and Campbell 2006). These knockout and other transgenic models will have utility for the study of muscle regeneration and serve as models to test therapeutic strategies to promote function and survival (Yasuda et al. 2005).

Accumulating evidence has established that age-related myopathies (i.e., sarcopenia) also have impaired regenerative defects. A number of the regenerative defects associated with aged muscle are due to the macro- and microenvironment (Carlson and Faulkner 1989, 1996; Coggan et al. 1992; Chakravarthy et al. 2000). Previous studies utilizing a transgenic strategy to overexpress Igf 1 have demonstrated increased satellite cell proliferation, mobilization of nonmuscle stem cells, and improved regeneration in skeletal muscle of aged mice (Musaro et al. 2001, 2004; Mourkioti and Rosenthal 2005). Mechanistically, the impaired proliferative capacity of satellite cells that reside in aged muscle has been shown to be due, in part, to perturbed Notch signaling, as forced expression of activated Notch restored the regeneration capacity of old (or aged) muscle (Conboy et al. 2003; Luo et al. 2005). Further studies undertaken by the Rando laboratory have utilized parabiosis to surgically join young and old mice to establish a shared circulatory system (Conboy et al. 2005). This strategy established that unknown circulating factors in young mice restore both the Notch signaling in satellite cells and muscle regeneration in aged mice (Conboy et al. 2005; Luo et al. 2005). Additional studies will be necessary to decipher the factors that modulate aged satellite cells as therapeutic targets for sarcopenia.

\section{Future perspectives}

In summary, skeletal muscle has a remarkable regenerative capacity due to resident stem cell populations. Recent studies have begun to define the genesis of the satellite cell pool and the regulatory cascades that direct discrete stages of the satellite cell pool. Future studies will further define the molecular regulation of these stages and define the hierarchy of stem cells and progenitors (i.e., transient amplifying cells) that reside in adult skeletal muscle. These results will enhance our understanding of somatic stem cell biology and serve as a platform for cell-based therapies directed toward patients with congenital birth defects and debilitating myopathies.

\section{Acknowledgments}

We acknowledge the results of investigators included and omitted (only due to space considerations) in this review who have contributed to the field of muscle regeneration. We acknowledge the contributions of Sean Goetsch for figure preparations and Drs. Cyprian Weaver and Mary Grace Garry for helpful discussions throughout the preparation of this review. We further thank Dr. David Goldhammer for providing the MyoD-GFP transgenic mouse model. Funding support was obtained from the National Institutes of Health (AR47850), the Donald W. Reynolds Foundation, and the Muscular Dystrophy Association. D.J.G. is an Established Investigator of the AHA. 


\section{References}

Akimoto, T., Ushida, T., Miyaki, S., Akaogi, H., Tsuchiya, K., Yan, Z., Williams, R.S., and Tateishi, T. 2005. Mechanical stretch inhibits myoblast-to-adipocyte differentiation through Wnt signaling. Biochem. Biophys. Res. Commun. 329: 381-385.

Allam, A.M. 1981. Satellite cells in the latissimus dorsi of the rat. Acta Anat. (Basel) 110: 287-290.

Allen, R.E. and Boxhorn, L.K. 1989. Regulation of skeletal muscle satellite cell proliferation and differentiation by transforming growth factor- $\beta$, insulin-like growth factor I, and fibroblast growth factor. J. Cell. Physiol. 138: 311-315.

Allikian, M.J., Hack, A.A., Mewborn, S., Mayer, U., and McNally, E.M. 2004. Genetic compensation for sarcoglycan loss by integrin $\alpha 7 \beta 1$ in muscle. J. Cell Sci. 117: 3821-3830.

Andermarcher, E., Surani, M.A., and Gherardi, E. 1996. Co-expression of the HGF/SF and c-met genes during early mouse embryogenesis precedes reciprocal expression in adjacent tissues during organogenesis. Dev. Genet. 18: 254-266.

Anderson, J.E. 2000. A role for nitric oxide in muscle repair: Nitric oxide-mediated activation of muscle satellite cells. Mol. Biol. Cell 11: 1859-1874.

Anderson, J. and Pilipowicz, O. 2002. Activation of muscle satellite cells in single-fiber cultures. Nitric Oxide 7: 36-41.

Armand, O., Boutineau, A.M., Mauger, A., Pautou, M.P., and Kieny, M. 1983. Origin of satellite cells in avian skeletal muscles. Arch. Anat. Microsc. Morphol. Exp. 72: 163-181.

Armand, A.S., Launay, T., Pariset, C., Della Gaspera, B., Charbonnier, F., and Chanoine, C. 2003. Injection of FGF6 accelerates regeneration of the soleus muscle in adult mice. Biochim. Biophys. Acta 1642: 97-105.

Asakura, A., Komaki, M., and Rudnicki, M. 2001. Muscle satellite cells are multipotential stem cells that exhibit myogenic, osteogenic, and adipogenic differentiation. Differentiation 68: 245-253.

Asakura, A., Seale, P., Girgis-Gabardo, A., and Rudnicki, M.A. 2002. Myogenic specification of side population cells in skeletal muscle. J. Cell Biol. 159: 123-134.

Auerbach, R. 1954. Analysis of the developmental effects of a lethal mutation in the house mouse. J. Exp. Zool. 127: 305329.

Austin, L. and Burgess, A.W. 1991. Stimulation of myoblast proliferation in culture by leukaemia inhibitory factor and other cytokines. J. Neurol. Sci. 101: 193-197.

Bachrach, E., Li, S., Perez, A.L., Schienda, J., Liadaki, K., Volinski, J., Flint, A., Chamberlain, J., and Kunkel, L.M. 2004. Systemic delivery of human microdystrophin to regenerating mouse dystrophic muscle by muscle progenitor cells. Proc. Nat1. Acad. Sci. 101: 3581-3586.

Bakay, M., Wang, Z., Melcon, G., Schiltz, L., Xuan, J., Zhao, P., Sartorelli, V., Seo, J., Pegoraro, E., Angelini, C., et al. 2006. Nuclear envelope dystrophies show a transcriptional fingerprint suggesting disruption of $\mathrm{Rb}-\mathrm{MyoD}$ pathways in muscle regeneration. Brain 129: 996-1013.

Barresi, R. and Campbell, K.P. 2006. Dystroglycan: From biosynthesis to pathogenesis of human disease. J. Cell Sci. 119: 199-207.

Barton, E.R., Morris, L., Musaro, A., Rosenthal, N., and Sweeney, H.L. 2002. Muscle-specific expression of insulin-like growth factor I counters muscle decline in $\mathrm{mdx}$ mice. J. Cell Biol. 157: 137-148.

Barton-Davis, E.R., Shoturma, D.I., Musaro, A., Rosenthal, N., and Sweeney, H.L. 1998. Viral mediated expression of insulin-like growth factor I blocks the aging-related loss of skeletal muscle function. Proc. Natl. Acad. Sci. 95: 15603-15607.
Beauchamp, J.R., Heslop, L., Yu, D.S., Tajbakhsh, S., Kelly, R.G., Wernig, A., Buckingham, M.E., Partridge, T.A., and Zammit, P.S. 2000. Expression of CD34 and myf5 defines the majority of quiescent adult skeletal muscle satellite cells. $J$. Cell Biol. 151: 1221-1234.

Bell, C.D. and Conen, P.E. 1968. Histopathological changes in Duchenne muscular dystrophy. J. Neurol. Sci. 7: 529-544.

Bendall, A.J., Ding, J., Hu, G., Shen, M.M., and Abate-Shen, C. 1999. Msx1 antagonizes the myogenic activity of Pax3 in migrating limb muscle precursors. Development 126: 49654976.

Beranger, F., Mejean, C., Moniot, B., Berta, P., and Vandromme, M. 2000. Muscle differentiation is antagonized by SOX15, a new member of the SOX protein family. J. Biol. Chem. 275: 16103-16109.

Bischoff, R. 1994. The satellite cell and muscle regeneration. In Myology (eds. A.G. Engel and C. Frazini-Armstrong), pp. 97118. McGraw-Hill, New York.

1997. Chemotaxis of skeletal muscle satellite cells. Dev. Dyn. 208: 505-515.

Bladt, F., Riethmacher, D., Isenmann, S., Aguzzi, A., and Birchmeier, C. 1995. Essential role for the c-met receptor in the migration of myogenic precursor cells into the limb bud. Nature 376: 768-771.

Blanpain, C., Lowry, W.E., Geoghegan, A., Polak, L., and Fuchs, E. 2004. Self-renewal, multipotency, and the existence of two cell populations within an epithelial stem cell niche. Cell 118: 635-648.

Bober, E., Franz, T., Arnold, H.H., Gruss, P., and Tremblay, P. 1994. Pax-3 is required for the development of limb muscles: A possible role for the migration of dermomyotomal muscle progenitor cells. Development 120: 603-612.

Borycki, A.G., Li, J., Jin, F., Emerson, C.P., and Epstein, J.A. 1999. Pax3 functions in cell survival and in pax7 regulation. Development 126: 1665-1674.

Braun, T., Buschhausen-Denker, G., Bober, E., Tannich, E., and Arnold, H.H. 1989. A novel human muscle factor related to but distinct from MyoD1 induces myogenic conversion in 10T1/2 fibroblasts. EMBO J. 8: 701-709.

Braun, T., Rudnicki, M.A., Arnold, H.H., and Jaenisch, R. 1992. Targeted inactivation of the muscle regulatory gene myf-5 results in abnormal rib development and perinatal death. Cell 71: 369-382.

Briguet, A., Courdier-Fruh, I., Foster, M., Meier, T., and Magyar, J.P. 2004. Histological parameters for the quantitative assessment of muscular dystrophy in the mdx-mouse. Neuromuscul. Disord. 14: 675-682.

Brohmann, H., Jagla, K., and Birchmeier, C. 2000. The role of Lbx1 in migration of muscle precursor cells. Development 127: 437-445.

Brown, S.C. and Stickland, N.C. 1993. Satellite cell content in muscles of large and small mice. J. Anat. 183: 91-96.

Buckingham, M., Bajard, L., Chang, T., Daubas, P., Hadchouel, J., Meilhac, S., Montarras, D., Rocancourt, D., and Relaix, F. 2003. The formation of skeletal muscle: From somite to limb. J. Anat. 202: 59-68.

Bulfield, G., Siller, W.G., Wight, P.A., and Moore, K.J. 1984. X chromosome-linked muscular dystrophy $(\mathrm{mdx})$ in the mouse. Proc. Natl. Acad. Sci. 81: 1189-1192.

Campion, D.R., Richardson, R.L., Reagan, J.O., and Kraeling, R.R. 1981. Changes in the satellite cell population during postnatal growth of pig skeletal muscle. J. Anim. Sci. 52: 1014-1018.

Carlson, B.M. and Faulkner, J.A. 1989. Muscle transplantation between young and old rats: Age of host determines recovery. Am. J. Physiol. Cell Physiol. 256: C1262-C1266. 
1996. The regeneration of noninnervated muscle grafts and marcaine-treated muscles in young and old rats. J. Gerontol. A Biol. Sci. Med. Sci. 51: B43-B49.

Chakravarthy, M.V., Davis, B.S., and Booth, F.W. 2000. IGF-I restores satellite cell proliferative potential in immobilized old skeletal muscle. J. Appl. Physiol. 89: 1365-1379.

Cheng, J., Baumhueter, S., Cacalano, G., Carver-Moore, K., Thibodeaux, H., Thomas, R., Broxmeyer, H.E., Cooper, S., Hague, N., Moore, M., et al. 1996. Hematopoietic defects in mice lacking the sialomucin CD34. Blood 87: 479-490.

Christ, B. and Ordahl, C.P. 1995. Early stages of chick somite development. Anat. Embryol. (Berl.) 191: 381-396.

Christ, B., Jacob, H.J., and Jacob, M. 1974. Origin of wing musculature. Experimental studies on quail and chick embryos. Experientia 30: 1446-1449.

Clarke, M.S., Khakee, R., and McNeil, P.L. 1993. Loss of cytoplasmic basic fibroblast growth factor from physiologically wounded myofibers of normal and dystrophic muscle. J. Cell Sci. 106: 121-133.

Clegg, C.H., Linkhart, T.A., Olwin, B.B., and Hauschka, S.D. 1987. Growth factor control of skeletal muscle differentiation: Commitment to terminal differentiation occurs in G1 phase and is repressed by fibroblast growth factor. J. Cell Biol. 105: 949-956.

Coggan, A.R., Spina, R.J., King, D.S., Rogers, M.A., Brown, M., Nemeth, P.M., and Holloszy, J.O. 1992. Histochemical and enzymatic comparison of the gastrocnemius muscle of young and elderly men and women. J. Gerontol. B Psychol. Sci. Soc. Sci. 47: B71-B76.

Collins, C.A., Olsen, I., Zammit, P.S., Heslop, L., Petrie, A., Partridge, T.A., and Morgan, J.E. 2005. Stem cell function, self-renewal, and behavioral heterogeneity of cells from the adult muscle satellite cell niche. Cell 122: 289-301.

Conboy, I.M. and Rando, T.A. 2002. The regulation of Notch signaling controls satellite cell activation and cell fate determination in postnatal myogenesis. Dev. Cell 3: 397-409.

Conboy, I.M., Conboy, M.J., Smythe, G.M., and Rando, T.A. 2003. Notch-mediated restoration of regenerative potential to aged muscle. Science 302: 1575-1577.

Conboy, I.M., Conboy, M.J., Wagers, A.J., Girma, E.R., Weissman, I.L., and Rando, T.A. 2005. Rejuvenation of aged progenitor cells by exposure to a young systemic environment. Nature 433: 760-764.

Corbel, S.Y., Lee, A., Yi, L., Duenas, J., Brazelton, T.R., Blau, H.M., and Rossi, F.M. 2003. Contribution of hematopoietic stem cells to skeletal muscle. Nat. Med. 9: 1528-1532.

Cornelison, D.D. and Wold, B.J. 1997. Single-cell analysis of regulatory gene expression in quiescent and activated mouse skeletal muscle satellite cells. Dev. Biol. 191: 270-283.

Cornelison, D.D., Filla, M.S., Stanley, H.M., Rapraeger, A.C., and Olwin, B.B. 2001. Syndecan-3 and syndecan-4 specifically mark skeletal muscle satellite cells and are implicated in satellite cell maintenance and muscle regeneration. Dev. Biol. 239: 79-94.

Cornelison, D.D., Wilcox-Adelman, S.A., Goetinck, P.F., Rauvala, H., Rapraeger, A.C., and Olwin, B.B. 2004. Essential and separable roles for Syndecan-3 and Syndecan-4 in skeletal muscle development and regeneration. Genes \& Dev. 18: 2231-2236.

Cossu, G. 1997. Unorthodox myogenesis: Possible developmental significance and implications for tissue histogenesis and regeneration. Histol. Histopathol. 12: 755-760.

Cossu, G. and Biressi, S. 2005. Satellite cells, myoblasts and other occasional myogenic progenitors: Possible origin, phenotypic features and role in muscle regeneration. Semin. Cell Dev. Biol. 16: 623-631.
Cossu, G. and Mavilio, F. 2000. Myogenic stem cells for the therapy of primary myopathies: Wishful thinking or therapeutic perspective? J. Clin. Invest. 105: 1669-1674.

Cossu, G., Tajbakhsh, S., and Buckingham, M. 1996. How is myogenesis initiated in the embryo? Trends Genet. 12: 218223.

Covault, J. and Sanes, J.R. 1986. Distribution of N-CAM in synaptic and extrasynaptic portions of developing and adult skeletal muscle. J. Cell Biol. 102: 716-730.

d'Albis, A., Couteaux, R., Janmot, C., Roulet, A., and Mira, J.C. 1988. Regeneration after cardiotoxin injury of innervated and denervated slow and fast muscles of mammals. Myosin isoform analysis. Eur. J. Biochem. 174: 103-110.

Davis, R.L., Weintraub, H., and Lassar, A.B. 1987. Expression of a single transfected cDNA converts fibroblasts to myoblasts. Cell 51: 987-1000.

De Angelis, L., Berghella, L., Coletta, M., Lattanzi, L., Zanchi, M., Cusella-De Angelis, M.G., Ponzetto, C., and Cossu, G. 1999. Skeletal myogenic progenitors originating from embryonic dorsal aorta coexpress endothelial and myogenic markers and contribute to postnatal muscle growth and regeneration. J. Cell Biol. 147: 869-878.

Deasy, B.M., Gharaibeh, B.M., Pollett, J.B., Jones, M.M., Lucas, M.A., Kanda, Y., and Huard, J. 2005. Long-term self-renewal of postnatal muscle-derived stem cells. Mol. Biol. Cell 16: 3323-3333.

Deconinck, A.E., Rafael, J.A., Skinner, J.A., Brown, S.C., Potter, A.C., Metzinger, L., Watt, D.J., Dickson, J.G., Tinsley, J.M., and Davies, K.E. 1997. Utrophin-dystrophin-deficient mice as a model for Duchenne muscular dystrophy. Cell 90: 717 727.

Dhawan, J. and Rando, T.A. 2005. Stem cells in postnatal myogenesis: Molecular mechanisms of satellite cell quiescence, activation and replenishment. Trends Cell Biol. 15: 666-673.

Dietrich, S., Schubert, F.R., Gruss, P., and Lumsden, A. 1999. The role of the notochord for epaxial myotome formation in the mouse. Cell. Mol. Biol. 45: 601-616.

DiMario, J.X., Uzman, A., and Strohman, R.C. 1991. Fiber regeneration is not persistent in dystrophic (MDX) mouse skeletal muscle. Dev. Biol. 148: 314-321.

Edmondson, D.G. and Olson, E.N. 1989. A gene with homology to the myc similarity region of MyoD1 is expressed during myogenesis and is sufficient to activate the muscle differentiation program. Genes \& Dev. 3: 628-640.

Enesco, M. and Puddy, D. 1964. Increase in the number of nuclei and weight in skeletal muscle of rats of various ages. Am. J. Anat. 114: 235-244.

Ferrari, G., Cusella-De Angelis, G., Coletta, M., Paolucci, E., Stornaiuolo, A., Cossu, G., and Mavilio, F. 1998. Muscle regeneration by bone marrow-derived myogenic progenitors. Science 279: 1528-1530.

Fiore, F., Sebille, A., and Birnbaum, D. 2000. Skeletal muscle regeneration is not impaired in $\mathrm{Fgf6}^{-/-}$mutant mice. Biochem. Biophys. Res. Commun. 272: 138-143.

Fischel, A. 1895. Zur entwicklung der ventralen rumpf- und extremitatenmuskulatur der Vogel und Saugetiere. Morphol. Jb. 23: 544-561.

Floss, T., Arnold, H.H., and Braun, T. 1997. A role for FGF-6 in skeletal muscle regeneration. Genes \& Dev. 11: 2040-2051.

Franz, T., Kothary, R., Surani, M.A., Halata, Z., and Grim, M. 1993. The Splotch mutation interferes with muscle development in the limbs. Anat. Embryol. (Berl.) 187: 153-160.

Frock, R., Kudlow, B., Evans, A., Jameson, S., Hauschka, S., and Kennedy, B. 2006. Lamin A/C and emerin are critical for skeletal muscle satellite cell differentiation. Genes \& Dev. 20: $486-500$. 
Fux, C., Mitta, B., Kramer, B.P., and Fussenegger, M. 2004. Dualregulated expression of C/EBP- $\alpha$ and BMP-2 enables differential differentiation of $\mathrm{C} 2 \mathrm{C} 12$ cells into adipocytes and osteoblasts. Nucleic Acids Res. 32: e1.

Galli, R., Borello, U., Gritti, A., Minasi, M.G., Bjornson, C. Coletta, M., Mora, M., De Angelis, M.G., Fiocco, R., Cossu, G., et al. 2000. Skeletal myogenic potential of human and mouse neural stem cells. Nat. Neurosci. 3: 986-991.

Garry, D.J., Yang, Q., Bassel-Duby, R., and Williams, R.S. 1997. Persistent expression of MNF identifies myogenic stem cells in postnatal muscles. Dev. Biol. 188: 280-294.

Garry, D.J., Meeson, A., Elterman, J., Zhao, Y., Yang, P., BasselDuby, R., and Williams, R.S. 2000. Myogenic stem cell function is impaired in mice lacking the forkhead/winged helix protein MNF. Proc. Nat1. Acad. Sci. 97: 5416-5421.

Gibson, M.C. and Schultz, E. 1982. The distribution of satellite cells and their relationship to specific fiber types in soleus and extensor digitorum longus muscles. Anat. Rec. 202: 329-337.

Goetsch, S.C., Hawke, T.J., Gallardo, T.D., Richardson, J.A., and Garry, D.J. 2003. Transcriptional profiling and regulation of the extracellular matrix during muscle regeneration. Physiol. Genomics 14: 261-271.

Goodell, M.A., Brose, K., Paradis, G., Conner, A.S., and Mulligan, R.C. 1996. Isolation and functional properties of murine hematopoietic stem cells that are replicating in vivo. J. Exp. Med. 183: 1797-1806.

Goodell, M.A., Rosenzweig, M., Kim, H., Marks, D.F., DeMaria, M., Paradis, G., Grupp, S.A., Sieff, C.A., Mulligan, R.C., and Johnson, R.P. 1997. Dye efflux studies suggest that hematopoietic stem cells expressing low or undetectable levels of CD34 antigen exist in multiple species. Nat. Med. 3: $1337-$ 1345.

Goulding, M., Lumsden, A., and Paquette, A.J. 1994. Regulation of Pax-3 expression in the dermomyotome and its role in muscle development. Development 120: 957-971.

Gros, J., Manceau, M., Thome, V., and Marcelle, C. 2005. A common somitic origin for embryonic muscle progenitors and satellite cells. Nature 435: 954-958.

Gross, M.K., Moran-Rivard, L., Velasquez, T., Nakatsu, M.N., Jagla, K., and Goulding, M. 2000. Lbx1 is required for muscle precursor migration along a lateral pathway into the limb. Development 127: 413-424.

Grounds, M.D., Garrett, K.L., Lai, M.C., Wright, W.E., and Beilharz, M.W. 1992. Identification of skeletal muscle precursor cells in vivo by use of MyoD1 and myogenin probes. Cell Tissue Res. 267: 99-104.

Gussoni, E., Soneoka, Y., Strickland, C.D., Buzney, E.A., Khan, M.K., Flint, A.F., Kunkel, L.M., and Mulligan, R.C. 1999. Dystrophin expression in the $\mathrm{mdx}$ mouse restored by stem cell transplantation. Nature 401: 390-394.

Gustafsson, M., Zheng, X., Pereira, T., Gradin, K., Jin, S., Lundkvist, J., Ruas, J., Poellinger, L., Lendahl, U., and Bondesson, M. 2005. Hypoxia requires Notch signaling to maintain the undifferentiated cell state. Dev. Cell 9: 617-628.

Halevy, O., Piestun, Y., Allouh, M.Z., Rosser, B.W., Rinkevich, Y., Reshef, R., Rozenboim, I., Wleklinski-Lee, M., and Yablonka-Reuveni, Z. 2004. Pattern of Pax7 expression during myogenesis in the posthatch chicken establishes a model for satellite cell differentiation and renewal. Dev. Dyn. 231: 489-502.

Hasty, P., Bradley, A., Morris, J.H., Edmondson, D.G., Venuti, J.M., Olson, E.N., and Klein, W.H. 1993. Muscle deficiency and neonatal death in mice with a targeted mutation in the myogenin gene. Nature 364: 501-506.

Hauschka, S.D. 1994. The embryonic origin of muscle. In My- ology (eds. A.G. Engel and C. Franzini-Armstrong), pp. 3-73. McGraw-Hill, New York.

Hawke, T.J. and Garry, D.J. 2001. Myogenic satellite cells: Physiology to molecular biology. J. Appl. Physiol. 91: 534551.

Hawke, T.J., Jiang, N., and Garry, D.J. 2003. Absence of p21CIP rescues myogenic progenitor cell proliferative and regenerative capacity in Foxk1 null mice. J. Biol. Chem. 278: 40154020.

Hoffman, E.P., Monaco, A.P., Feener, C.C., and Kunkel, L.M. 1987. Conservation of the Duchenne muscular dystrophy gene in mice and humans. Science 238: 347-350.

Hollnagel, A., Grund, C., Franke, W.W., and Arnold, H.H. 2002. The cell adhesion molecule M-cadherin is not essential for muscle development and regeneration. Mol. Cell. Biol. 22: 4760-4770.

Holst, D., Luquet, S., Kristiansen, K., and Grimaldi, P.A. 2003. Roles of peroxisome proliferator-activated receptors $\delta$ and $\gamma$ in myoblast transdifferentiation. Exp. Cell Res. 288: 168176.

Holterman, C.E. and Rudnicki, M.A. 2005. Molecular regulation of satellite cell function. Semin. Cell Dev. Biol. 16: 575-584.

Horsley, V., Jansen, K.M., Mills, S.T., and Pavlath, G.K. 2003. IL-4 acts as a myoblast recruitment factor during mammalian muscle growth. Cell 113: 483-494.

Hu, E., Tontonoz, P., and Spiegelman, B.M. 1995. Transdifferentiation of myoblasts by the adipogenic transcription factors PPAR $\gamma$ and C/EBP $\alpha$. Proc. Natl. Acad. Sci. 92: 98569860.

Irintchev, A., Zeschnigk, M., Starzinski-Powitz, A., and Wernig, A. 1994. Expression pattern of M-cadherin in normal, denervated, and regenerating mouse muscles. Dev. Dyn. 199: 326337.

Jackson, K.A., Mi, T., and Goodell, M.A. 1999. Hematopoietic potential of stem cells isolated from murine skeletal muscle. Proc. Natl. Acad. Sci. 96: 14482-14486.

Jesse, T.L., LaChance, R., Iademarco, M.F., and Dean, D.C. 1998. Interferon regulatory factor- 2 is a transcriptional activator in muscle where it regulates expression of vascular cell adhesion molecule-1. J. Cell Biol. 140: 1265-1276.

Jiang, Y., Jahagirdar, B.N., Reinhardt, R.L., Schwartz, R.E., Keene, C.D., Ortiz-Gonzalez, X.R., Reyes, M., Lenvik, T., Lund, T., Blackstad, M., et al. 2002. Pluripotency of mesenchymal stem cells derived from adult marrow. Nature 418: 41-49.

Johnson, S.E. and Allen, R.E. 1995. Activation of skeletal muscle satellite cells and the role of fibroblast growth factor receptors. Exp. Cell Res. 219: 449-453.

Jones, N.C., Fedorov, Y.V., Rosenthal, R.S., and Olwin, B.B. 2001. ERK1/2 is required for myoblast proliferation but is dispensable for muscle gene expression and cell fusion. $J$. Cell. Physiol. 186: 104-115.

Jones, N.C., Tyner, K., Nibarger, L., Stanley, H., Cornelison, D., Fedorow, Y., and Olwin, B. 2005. The p38 $\alpha / \beta$ MAPK functions as a molecular switch to activate the quiescent satellite cell. J. Cell Biol. 169: 105-116.

Kablar, B., Krastel, K., Tajbakhsh, S., and Rudnicki, M.A. 2003. Myf5 and MyoD activation define independent myogenic compartments during embryonic development. Dev. Biol. 258: $307-318$.

Kambadur, R., Sharma, M., Smith, T.P., and Bass, J.J. 1997. Mutations in myostatin (GDF8) in double-muscled Belgian Blue and Piedmontese cattle. Genome Res. 7: 910-916.

Kassar-Duchossoy, L., Gayraud-Morel, B., Gomes, D., Rocancourt, D., Buckingham, M., Shinin, V., and Tajbakhsh, S. 
2004. Mrf4 determines skeletal muscle identity in Myf5:Myod double-mutant mice. Nature 431: 466-471.

Krause, D.S., Ito, T., Fackler, M.J., Smith, O.M., Collector, M.I., Sharkis, S.J., and May, W.S. 1994. Characterization of murine CD34, a marker for hematopoietic progenitor and stem cells. Blood 84: 691-701.

Kuang, S., Charge, S.B., Seale, P., Huh, M., and Rudnicki, M.A. 2006. Distinct roles for Pax7 and Pax3 in adult regenerative myogenesis. J. Cell Biol. 172: 103-113.

Kurek, J.B., Bower, J.J., Romanella, M., Koentgen, F., Murphy, M., and Austin, L. 1997. The role of leukemia inhibitory factor in skeletal muscle regeneration. Muscle Nerve 20: 815-822.

LaBarge, M.A. and Blau, H.M. 2002. Biological progression from adult bone marrow to mononucleate muscle stem cell to multinucleate muscle fiber in response to injury. Cell 111: 589-601.

Lassar, A.B., Davis, R.L., Wright, W.E., Kadesch, T., Murre, C., Voronova, A., Baltimore, D., and Weintraub, H. 1991. Functional activity of myogenic HLH proteins requires heterooligomerization with E12/E47-like proteins in vivo. Cell 66: 305-315.

Laws, N. and Hoey, A. 2004. Progression of kyphosis in $\mathrm{mdx}$ mice. J. Appl. Physiol. 97: 1970-1977.

Le Douarin, N. and Barq, G. 1969. Use of Japanese quail cells as 'biological markers' in experimental embryology. C.R. Acad. Sci. Hebd. Seances Acad. Sci. D 269: 1543-1546.

Lee, J.Y., Qu-Petersen, Z., Cao, B., Kimura, S., Jankowski, R., Cummins, J., Usas, A., Gates, C., Robbins, P., Wernig, A., et al. 2000. Clonal isolation of muscle-derived cells capable of enhancing muscle regeneration and bone healing. I. Cell Biol. 150: 1085-1100.

Lee, H.J., Goring, W., Ochs, M., Muhlfeld, C., Steding, G., Paprotta, I., Engel, W., and Adham, I.M. 2004. Sox15 is required for skeletal muscle regeneration. Mol. Cell. Biol. 24: 84288436.

LeRoith, D., McGuinness, M., Shemer, J., Stannard, B., Lanau, F., Faria, T.N., Kato, H., Werner, H., Adamo, M., and Roberts, C.T. 1992. Insulin-like growth factors. Biol. Signals 1: $173-181$.

Li, Y.-P. 2003. TNF- $\alpha$ is a mitogen in skeletal muscle. Am. J. Physiol. Cell Physiol. 285: C370-C376.

Lluís, F., Perdiguero, E., Nebreda, A.R., and Muñoz-Cánoves, P. 2006. Regulation of skeletal muscle gene expression by p38 MAP kinases. Trends Cell Biol. 16: 36-44.

Lu, J.R., Bassel-Duby, R., Hawkins, A., Chang, P., Valdez, R., Wu, H., Gan, L., Shelton, J.M., Richardson, J.A., and Olson, E.N. 2002. Control of facial muscle development by MyoR and capsulin. Science 298: 2378-2381.

Luo, D., Renault, V.M., and Rando, T.A. 2005. The regulation of Notch signaling in muscle stem cell activation and postnatal myogenesis. Semin. Cell Dev. Biol. 16: 612-622.

Maina, F., Casagranda, F., Audero, E., Simeone, A., Comoglio, P.M., Klein, R., and Ponzetto, C. 1996. Uncoupling of Grb2 from the Met receptor in vivo reveals complex roles in muscle development. Cell 87: 531-542.

Mansouri, A., Stoykova, A., Torres, M., and Gruss, P. 1996. Dysgenesis of cephalic neural crest derivatives in $\mathrm{Pax}^{-/-}$ mutant mice. Development 122: 831-838.

Maroto, M., Reshef, R., Munsterberg, A.E., Koester, S., Goulding, M., and Lassar, A.B. 1997. Ectopic Pax-3 activates MyoD and Myf-5 expression in embryonic mesoderm and neural tissue. Cell 89: 139-148.

Martin, J.F., Li, L., and Olson, E.N. 1992. Repression of myogenin function by TGF- $\beta 1$ is targeted at the basic helix-loophelix motif and is independent of E2A products. J. Biol.
Chem. 267: 10956-10960.

Martin, C.M., Meeson, A.P., Robertson, S.M., Hawke, T.J., Richardson, J.A., Bates, S., Goetsch, S.C., Gallardo, T.D., and Garry, D.J. 2004. Persistent expression of the ATP-binding cassette transporter, Abcg2, identifies cardiac SP cells in the developing and adult heart. Dev. Biol. 265: 262-275.

Matsuda, R., Nishikawa, A., and Tanaka, H. 1995. Visualization of dystrophic muscle fibers in $m d x$ mouse by vital staining with Evans blue: Evidence of apoptosis in dystrophin-deficient muscle. J. Biochem. 118: 959-964.

Mauro, A. 1961. Satellite cell of skeletal muscle fibers. J. Biophys. Biochem. Cytol. 9: 493-498.

McCroskery, S., Thomas, M., Maxwell, L., Sharma, M., and Kambadur, R. 2003. Myostatin negatively regulates satellite cell activation and self-renewal. J. Cell Biol. 162: 1135-1147.

McCroskery, S., Thomas, M., Platt, L., Hennebry, A., Nishimura, T., McLeay, L., Sharma, M., and Kambadur, R. 2005. Improved muscle healing through enhanced regeneration and reduced fibrosis in myostatin-null mice. J. Cell Sci. 118: 3531-3541.

McNally, E.M. and MacLeod, H. 2005. Therapy insight: Cardiovascular complications associated with muscular dystrophies. Nat. Clin. Pract. Cardiovasc. Med. 2: 301-308.

McPherron, A.C., Lawler, A.M., and Lee, S.J. 1997. Regulation of skeletal muscle mass in mice by a new TGF- $\beta$ superfamily member. Nature 387: 83-90.

Meeson, A.P., Hawke, T.J., Graham, S., Jiang, N., Elterman, J., Hutcheson, K., Dimaio, J.M., Gallardo, T.D., and Garry, D.J. 2004. Cellular and molecular regulation of skeletal muscle side population cells. Stem Cells 22: 1305-1320.

Megeney, L.A., Kablar, B., Garrett, K., Anderson, J.E., and Rudnicki, M.A. 1996. MyoD is required for myogenic stem cell function in adult skeletal muscle. Genes \& Dev. 10: 11731183.

Melcon, G., Kozlov, S., Cutler, D., Sullivan, T., Hernandez, L., Zhao, P., Mitchell, S., Nader, G., Bakay, M., Rottman, J., et al. 2006. Loss of emerin at the nuclear envelope disrupts the Rb1/E2F ad MyoD pathways during muscle regeneration. Hum. Mol. Genet. 15: 637-651.

Michalopoulos, G.K. and Zarnegav, R. 1992. Hepatocyte growth factor. Hepatology 15: 149-155.

Miller, J.B., Schaefer, L., and Dominov, J.A. 1999. Seeking muscle stem cells. Curr. Top. Dev. Biol. 43: 191-219.

Miller, K.J., Thaloor, D., Matteson, S., and Pavlath, G.K. 2000. Hepatocyte growth factor affects satellite cell activation and differentiation in regenerating skeletal muscle. Am. I. Physiol. Cell Physiol. 278: C174-C181.

Minasi, M.G., Riminucci, M., De Angelis, L., Borello, U., Berarducci, B., Innocenzi, A., Caprioli, A., Sirabella, D., Baiocchi, M., De Maria, R., et al. 2002. The meso-angioblast: A multipotent, self-renewing cell that originates from the dorsal aorta and differentiates into most mesodermal tissues. Development 129: 2773-2783.

Mitchell, P.O., Mills, T., O'Connor, R.S., Graubert, T., Dzierzak, E., and Pavlath, G.K. 2005. Sca-1 negatively regulates proliferation and differentiation of muscle cells. Dev. Biol. 283: $240-252$.

Montanaro, F., Liadaki, K., Schienda, J., Flint, A., Gussoni, E., and Kunkel, L.M. 2004. Demystifying SP cell purification: Viability, yield, and phenotype are defined by isolation parameters. Exp. Cell Res. 298: 144-154.

Montarras, D., Morgan, J., Collins, C., Relaix, F., Zaffran, S., Cumano, A., Partridge, T., and Buckingham, M. 2005. Direct isolation of satellite cells for skeletal muscle regeneration. Science 309: 2064-2067.

Moss, F.P. and Leblond, C.P. 1971. Satellite cells as the source 
of nuclei in muscles of growing rats. Anat. Rec. 170: 421435.

Motoike, T., Markham, D.W., Rossant, J., and Sato, T.N. 2003. Evidence for novel fate of Flk $1^{+}$progenitor: Contribution to muscle lineage. Genesis 35: 153-159.

Mourkioti, F. and Rosenthal, N. 2005. IGF-1, inflammation and stem cells: Interactions during muscle regeneration. Trends Immunol. 26: 535-542.

Muguruma, Y., Reyes, M., Nakamura, Y., Sato, T., Matsuzawa, H., Miyatake, H., Akatsuka, A., Itoh, J., Yahata, T., Ando, K., et al. 2003. In vivo and in vitro differentiation of myocytes from human bone marrow-derived multipotent progenitor cells. Exp. Hematol. 31: 1323-1330.

Muir, A.R., Kanji, A.H., and Allbrook, D. 1965. The structure of the satellite cells in skeletal muscle. J. Anat. 99: 435-444.

Munsterberg, A.E. and Lassar, A.B. 1995. Combinatorial signals from the neural tube, floor plate and notochord induce myogenic bHLH gene expression in the somite. Development 121: 651-660.

Musaro, A., McCullagh, K., Paul, A., Houghton, L., Dobrowolny, G., Molinaro, M., Barton, E.R., Sweeney, H.L., and Rosenthal, N. 2001. Localized Igf-1 transgene expression sustains hypertrophy and regeneration in senescent skeletal muscle. Nat. Genet. 27: 195-200.

Musaro, A., Giacinti, C., Borsellino, G., Dobrowolny, G., Pelosi, L., Cairns, L., Ottolenghi, S., Cossu, G., Bernardi, G., Battistini, L., et al. 2004. Stem cell-mediated muscle regeneration is enhanced by local isoform of insulin-like growth factor 1 . Proc. Natl. Acad. Sci. 101: 1206-1210.

Nabeshima, Y., Hanaoka, K., Hayasaka, M., Esumi, E., Li, S., Nonaka, I., and Nabeshima, Y. 1993. Myogenin gene disruption results in perinatal lethality because of severe muscle defect. Nature 364: 532-535.

Nathan, C.F. 1987. Secretory products of macrophages. J. Clin. Invest. 79: 319-326.

Nicolas, N., Gallien, C.L., and Chanoine, C. 1996. Analysis of MyoD, myogenin, and muscle-specific gene mRNAs in regenerating Xenopus skeletal muscle. Dev. Dyn. 207: 60-68.

Olguin, H.C. and Olwin, B.B. 2004. Pax-7 up-regulation inhibits myogenesis and cell cycle progression in satellite cells: A potential mechanism for self-renewal. Dev. Biol. 275: 375388.

Ordahl, C.P., Williams, B.A., and Denetclaw, W. 2000. Determination and morphogenesis in myogenic progenitor cells: An experimental embryological approach. Curr. Top. Dev. Biol. 48: 319-367.

Oustanina, S., Hause, G., and Braun, T. 2004. Pax7 directs postnatal renewal and propagation of myogenic satellite cells but not their specification. EMBO J. 23: 3430-3439.

Palermo, A.T., Labarge, M.A., Doyonnas, R., Pomerantz, J., and Blau, H.M. 2005. Bone marrow contribution to skeletal muscle: A physiological response to stress. Dev. Biol. 279: 336-344.

Patapoutian, A., Yoon, J.K., Miner, J.H., Wang, S., Stark, K., and Wold, B. 1995. Disruption of the mouse MRF4 gene identifies multiple waves of myogenesis in the myotome. Development 121: 3347-3358.

Pinney, D.F., Pearson-White, S.H., Konieczny, S.F., Latham, K.E., and Emerson Jr., C.P. 1988. Myogenic lineage determination and differentiation: Evidence for a regulatory gene pathway. Cell 53: 781-793.

Pirskanen, A., Kiefer, J.C., and Hauschka, S.D. 2000. IGFs, insulin, Shh, bFGF, and TGF- $\beta 1$ interact synergistically to promote somite myogenesis in vitro. Dev. Biol. 224: 189-203.

Polesskaya, A., Seale, P., and Rudnicki, M.A. 2003. Wnt signaling induces the myogenic specification of resident CD $45^{+}$ adult stem cells during muscle regeneration. Cell 113: 841852.

Porter, J.D., Merriam, A.P., Leahy, P., Gong, B., and Khanna, S. 2003. Dissection of temporal gene expression signatures of affected and spared muscle groups in dystrophin-deficient $(\mathrm{mdx})$ mice. Hum. Mol. Genet. 12: 1813-1821.

Quinlan, J.G., Hahn, H.S., Wong, B.L., Lorenz, J.N., Wenisch, A.S., and Levin, L.S. 2004. Evolution of the mdx mouse cardiomyopathy: Physiological and morphological findings. Neuromuscul. Disord. 14: 491-496.

Quinn, L.S., Strait-Bodey, L., Anderson, B.G., Argiles, J.M., and Havel, P.J. 2005. Interleukin-15 stimulates adiponectin secretion by 3T3-L1 adipocytes: Evidence for a skeletal muscle-to-fat signaling pathway. Cell Biol. Int. 29: 449-457.

Rando, T.A. and Blau, H.M. 1994. Primary mouse myoblast purification, characterization, and transplantation for cell-mediated gene therapy. J. Cell Biol. 125: 1275-1287.

Rapraeger, A.C., Krufka, A., and Olwin, B.B. 1991. Requirement of heparan sulfate for bFGF-mediated fibroblast growth and myoblast differentiation. Science 52: 1705-1708.

Rawls, A., Wilson-Rawls, J., and Olson, E.N. 2000. Genetic regulation of somite formation. Curr. Top. Dev. Biol. 47: 131-154.

Relaix, F., Rocancourt, D., Mansouri, A., and Buckingham, M. 2004. Divergent functions of murine Pax3 and Pax7 in limb muscle development. Genes \& Dev. 18: 1088-1105.

- 2005. A Pax3/Pax7-dependent population of skeletal muscle progenitor cells. Nature 435: 948-953.

Relaix, F., Montarras, D., Zaffran, S., Gayraud-Morel, B., Rocancourt, D., Tajbakhsh, S., Mansouri, A., Cumano, A., and Buckingham, M. 2006. Pax3 and Pax7 have distinct and overlapping functions in adult muscle progenitor cells. J. Cell Biol. 172: 91-102.

Reyes, M., Li, S., Foraker, J., Kimura, E., and Chamberlain, J.S. 2005. Donor origin of multipotent adult progenitor cells in radiation chimeras. Blood 106: 3646-3649.

Rhodes, S.J. and Konieczny, S.F. 1989. Identification of MRF4: A new member of the muscle regulatory factor gene family. Genes \& Dev. 3: 2050-2061.

Ross, S.E., Hemati, N., Longo, K.A., Bennett, C.N., Lucas, P.C., Erickson, R.L., and MacDougald, O.A. 2000. Inhibition of adipogenesis by Wnt signaling. Science 289: 950-953.

Rudnicki, M.A., Braun, T., Hinuma, S., and Jaenisch, R. 1992. Inactivation of MyoD in mice leads to up-regulation of the myogenic HLH gene Myf-5 and results in apparently normal muscle development. Cell 71: 383-390.

Rudnicki, M.A., Schnegelsberg, P.N.J., Stead, R.H., Braun, T., Arnold, H.H., and Jaenish, R. 1993. MyoD or Myf-5 is required for the formation of skeletal muscle. Cell 75: 13511359.

Sampaolesi, M., Torrente, Y., Innocenzi, A., Tonlorenzi, R., D'Antona, G., Pellegrino, M.A., Barresi, R., Bresolin, N., De Angelis, M.G., Campbell, K.P., et al. 2003. Cell therapy of $\alpha$-sarcoglycan null dystrophic mice through intra-arterial delivery of mesoangioblasts. Science 301: 487-492.

Sassoon, D., Lyons, G., Wright, W.E., Lin, V., Lassar, A., Weintraub, H., and Buckingham, M. 1989. Expression of two myogenic regulatory factors myogenin and MyoD1 during mouse embryogenesis. Nature 341: 303-307.

Schienda, J., Engleka, K.A., Jun, S., Hansen, M.S., Epstein, J.A., Tabin, C.J., Kunkel, L.M., and Kardon, G. 2006. Somitic origin of limb muscle satellite and side population cells. Proc. Nat1. Acad. Sci. 103: 945-950.

Schmalbruch, H. and Hellhammer, U. 1977. The number of nuclei in adult rat muscles with special reference to satellite cells. Anat. Rec. 189: 169-175. 
Schmidt, K., Glaser, G., Wernig, A., Wegner, M., and Rosorius, O. 2003. Sox8 is a specific marker for muscle satellite cells and inhibits myogenesis. J. Biol. Chem. 278: 29769-29775.

Schultz, E. 1996. Satellite cell proliferative compartments in growing skeletal muscles. Dev. Biol. 175: 84-94.

Schultz, E. and Jaryszak, D.L. 1985. Effects of skeletal muscle regeneration on the proliferation potential of satellite cells. Mech. Ageing Dev. 30: 63-72.

Schultz, E. and McCormick, K.M. 1994. Skeletal muscle satellite cells. Rev. Physiol. Biochem. Pharmacol. 123: 213-257.

Seale, P., Sabourin, L.A., Girgis-Gabardo, A., Mansouri, A., Gruss, P., and Rudnicki, M.A. 2000. Pax7 is required for the specification of myogenic satellite cells. Cell 102: 777-786.

Seale, P., Ishibashi, J., Scime, A., and Rudnicki, M.A. 2004. Pax7 is necessary and sufficient for the myogenic specification of $\mathrm{CD} 45^{+}: \mathrm{Sca}^{+}$stem cells from injured muscle. PLoS Biol. 2: E130.

Seed, J. and Hauschka, S.D. 1988. Clonal analysis of vertebrate myogenesis. VIII. Fibroblasts growth factor (FGF)-dependent and FGF-independent muscle colony types during chick wing development. Dev. Biol. 128: 40-49.

Shavlakadze, T., White, J., Hoh, J.F., Rosenthal, N., and Grounds, M.D. 2004. Targeted expression of insulin-like growth factor-I reduces early myofiber necrosis in dystrophic mdx mice. Mol. Ther. 10: 829-843.

Sheehan, S.M. and Allen, R.E. 1999. Skeletal muscle satellite cell proliferation in response to members of the fibroblast growth factor family and hepatocyte growth factor. J. Cell. Physiol. 181: 499-506.

Sheehan, S.M., Tatsumi, R., Temm-Grove, C.J., and Allen, R.E. 2000. HGF is an autocrine growth factor for skeletal muscle satellite cells in vitro. Muscle Nerve 23: 239-245.

Shefer, G., Wleklinski-Lee, M., and Yablonka-Reuveni, Z. 2004. Skeletal muscle satellite cells can spontaneously enter an alternative mesenchymal pathway. J. Cell Sci. 117: 53935404.

Sherwood, R.I., Christensen, J.L., Weissman, I.L., and Wagers, A.J. 2004. Determinants of skeletal muscle contributions from circulating cells, bone marrow cells, and hematopoietic stem cells. Stem Cells 22: 1292-1304.

Snow, M.H. 1977. The effects of aging on satellite cells in skeletal muscles of mice and rats. Cell Tissue Res. 185: 399-408.

Song, Y.H., Godard, M., Li, Y., Richmond, S.R., Rosenthal, N., and Delafontaine, P. 2005. Insulin-like growth factor I-mediated skeletal muscle hypertrophy is characterized by increased mTOR-p70S6K signaling without increased Akt phosphorylation. J. Investig. Med. 53: 135-142.

Sordella, R., Jiang, W., Chen, G.C., Curto, M., and Settleman, J. 2003. Modulation of Rho GTPase signaling regulates a switch between adipogenesis and myogenesis. Cell 113: 147-158.

Straub, V., Rafael, J.A., Chamberlain, J.S., and Campbell, K.P. 1997. Animal models for muscular dystrophy show different patterns of sarcolemmal disruption. J. Cell Biol. 139: 375385.

Tajbakhsh, S. 2005. Skeletal muscle stem and progenitor cells: Reconciling genetics and lineage. Exp. Cell Res. 306: 364372.

Tajbakhsh, S., Rocancourt, D., Cossu, G., and Buckingham, M. 1997. Redefining the genetic hierarchies controlling skeletal myogenesis: Pax-3 and Myf-5 act upstream of MyoD. Cell 89: $127-138$

Tamaki, T., Akatsuka, A., Ando, K., Nakamura, Y., Matsuzawa, H., Hotta, T., Roy, R.R., and Edgerton, V.R. 2002. Identification of myogenic-endothelial progenitor cells in the interstitial spaces of skeletal muscle. J. Cell Biol. 157: 571-577.
Tamaki, T., Uchiyama, Y., Okada, Y., Ishikawa, T., Sato, M., Akatsuka, A., and Asahara, T. 2005. Functional recovery of damaged skeletal muscle through synchronized vasculogenesis, myogenesis, and neurogenesis by muscle-derived stem cells. Circulation 112: 2857-2866.

Tapscott, S.J., Davis, R.L., Thayer, M.J., Cheng, P.F., Weintraub, H., and Lassar, A.B. 1988. MyoD1: A nuclear phosphoprotein requiring a Myc homology region to convert fibroblasts to myoblasts. Science 242: 405-411.

Tatsumi, R. and Allen, R.E. 2004. Active hepatocyte growth factor is present in skeletal muscle extracellular matrix. Muscle Nerve 30: 654-658.

Tatsumi, R., Anderson, J.E., Nevoret, C.J., Halevy, O., and Allen, R.E. 1998. HGF/SF is present in normal adult skeletal muscle and is capable of activating satellite cells. Dev. Biol. 194: $114-128$.

Tatsumi, R., Hattori, A., Ikeuchi, Y., Anderson, J.E., and Allen, R.E. 2002. Release of hepatocyte growth factor from mechanically stretched skeletal muscle satellite cells and role of pH and nitric oxide. Mol. Biol. Cell 13: 2909-2918.

Tavian, M., Zheng, B., Oberlin, E., Crisan, M., Sun, B., Huard, J., and Peault, B. 2005. The vascular wall as a source of stem cells. Ann. N. Y. Acad. Sci. 1044: 41-50.

Taylor-Jones, J.M., McGehee, R.E., Rando, T.A., Lecka-Czernik, B., Lipschitz, D.A., and Peterson, C.A. 2002. Activation of an adipogenic program in adult myoblasts with age. Mech. Ageing Dev. 123: 649-661.

Tseng, B.S., Zhao, P., Pattison, J.S., Gordon, S.E., Granchelli, J.A., Madsen, R.W., Folk, L.C., Hoffman, E.P., and Booth, F.W. 2002. Regenerated $\mathrm{mdx}$ mouse skeletal muscle shows differential mRNA expression. J. Appl. Physiol. 93: 537-545.

Turk, R., Sterrenburg, E., de Meijer, E.J., van Ommen, G.J., den Dunnen, J.T., and 't Hoen, P.A. 2005. Muscle regeneration in dystrophin-deficient $\mathrm{mdx}$ mice studied by gene expression profiling. BMC Genomics 6: 98.

Vertino, A.M., Taylor-Jones, J.M., Longo, K.A., Bearden, E.D., Lane, T.F., McGehee Jr., R.E., MacDougald, O.A., and Peterson, C.A. 2005. Wnt10b deficiency promotes coexpression of myogenic and adipogenic programs in myoblasts. Mol. Biol. Cell 16: 2039-2048.

Wang, Y. and Sassoon, D. 1995. Ectoderm-mesenchyme and mesenchyme-mesenchyme interactions regulate Msx-1 expression and cellular differentiation in the murine limb bud. Dev. Biol. 168: 374-382.

Watkins, S.C. and Cullen, M.J. 1988. A quantitative study of myonuclear and satellite cell nuclear size in Duchenne's muscular dystrophy, polymyositis and normal human skeletal muscle. Anat. Rec. 222: 6-11.

Weintraub, H. 1993. The MyoD family and myogenesis: Redundancy, networks, and thresholds. Cell 75: 1241-1244.

Weintraub, H., Tapscott, S.J., Davis, R.L., Thayer, M.J., Adam, M.A., Lassar, A.B., and Miller, A.D. 1989. Activation of muscle-specific genes in pigment, nerve, fat, liver, and fibroblast cell lines by forced expression of MyoD. Proc. Nat1. Acad. Sci. 86: 5434-5438.

Weissman, I.L. 2000. Stem cells: Units of development, units of regeneration, and units in evolution. Cell 100: 157-168.

Weston, A., Sampaio, A., Ridgeway, A., and Underhill, T. 2003. Inhibition of p38 MAPK signaling promotes late stages of myogenesis. J. Cell Sci. 116: 2885-2893.

Wilson, M. and Koopman, P. 2002. Matching SOX: Partner proteins and co-factors of the SOX family of transcriptional regulators. Curr. Opin. Genet. Dev. 12: 441-446.

Wokke, J.H., Van den Oord, C.J., Leppink, G.J., and Jennekens, F.G. 1989. Perisynaptic satellite cells in human external intercostal muscle: A quantitative and qualitative study. Anat. 
Rec. 223: 174-180.

Wozniak, A.C., Kong, J., Bock, E., Pilipowicz, O., and Anderson, J.E. 2005. Signaling satellite-cell activation in skeletal muscle: Markers, models, stretch, and potential alternate pathways. Muscle Nerve 31: 283-300.

Wright, W.E., Sassoon, D.A., and Lin, V.K. 1989. Myogenin, a factor regulating myogenesis, has a domain homologous to MyoD. Cell 56: 607-617.

Yablonka-Reuveni, Z. and Anderson, J.E. 2006. Satellite cells from dystrophic $(\mathrm{mdx})$ mice display accelerated differentiation in primary cultures and in isolated myofibers. Dev. Dyn. 235: 203-212.

Yan, Z., Choi, S., Liu, X., Zhang, M., Schageman, J.J., Lee, S.Y., Hart, R., Lin, L., Thurmond, F.A., and Williams, R.S. 2003. Highly coordinated gene regulation in mouse skeletal muscle regeneration. J. Biol. Chem. 278: 8826-8836.

Yang, X.M., Vogan, K., Gros, P., and Park, M. 1996. Expression of the met receptor tyrosine kinase in muscle progenitor cells in somites and limbs is absent in Splotch mice. Development 122: 2163-2171.

Yasuda, S., Townsend, D., Michele, D.E., Favre, E.G., Day, S.M., and Metzger, J.M. 2005. Dystrophic heart failure blocked by membrane sealant poloxamer. Nature 436: 1025-1029.

Young, P.E., Baumhueter, S., and Lasky, L.A. 1995. The sialomucin CD34 is expressed on hematopoietic cells and blood vessels during murine development. Blood 85: 96-105.

Zammit, P.S., Golding, J.P., Nagata, Y., Hudon, V., Partridge, T.A., and Beauchamp, J.R. 2004. Muscle satellite cells adopt divergent fates: A mechanism for self-renewal? J. Cell Biol. 166: $347-357$.

Zhang, W., Behringer, R.R., and Olson, E.N. 1995. Inactivation of the myogenic bHLH gene MRF4 results in upregulation of myogenin and rib anomalies. Genes \& Dev. 9: 1388-1399.

Zhao, P. and Hoffman, E.P. 2004. Embryonic myogenesis pathways in muscle regeneration. Dev. Dyn. 229: 380-392.

Zhou, S., Schuetz, J.D., Bunting, K.D., Colapietro, A.M., Sampath, J., Morris, J.J., Lagutina, I., Grosveld, G.C., Osawa, M., Nakauchi, H., et al. 2001. The ABC transporter Bcrp1/ ABCG2 is expressed in a wide variety of stem cells and is a molecular determinant of the side-population phenotype. Nat. Med. 7: 1028-1034. 


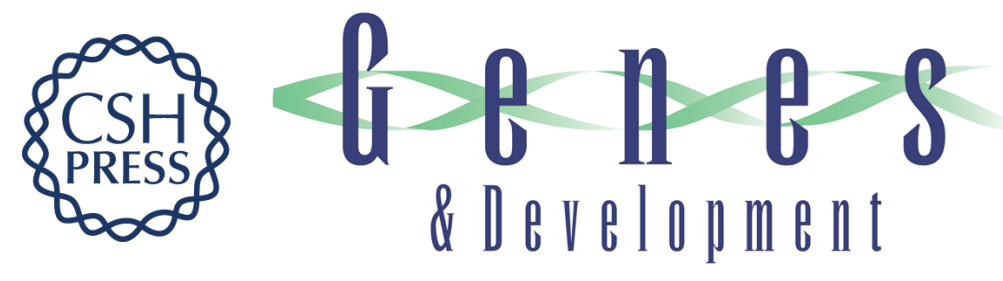

\section{Muscle stem cells in development, regeneration, and disease}

Xiaozhong Shi and Daniel J. Garry

Genes Dev. 2006, 20:

Access the most recent version at doi:10.1101/gad.1419406

References This article cites 227 articles, 78 of which can be accessed free at: http://genesdev.cshlp.org/content/20/13/1692.full.html\#ref-list-1

License

Email Alerting Receive free email alerts when new articles cite this article - sign up in the box at the top Service right corner of the article or click here.

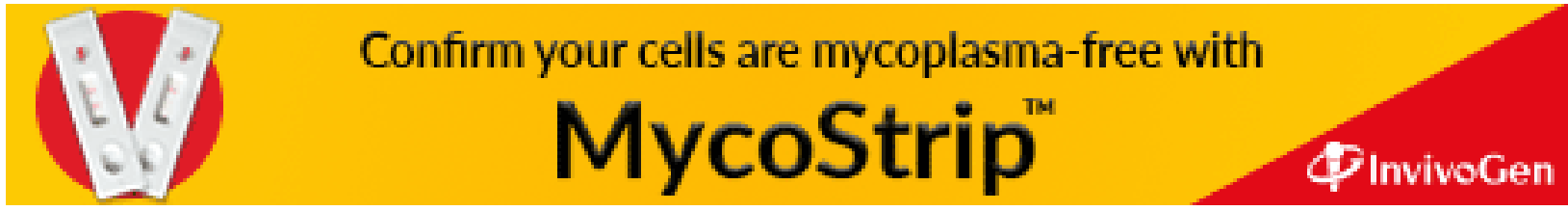

